\title{
Biological invasion of European tomato crops by Tuta absoluta: ecology, geographic expansion and prospects for biological control
}

\author{
Nicolas Desneux • Eric Wajnberg • Kris A. G. Wyckhuys • Giovanni Burgio • \\ Salvatore Arpaia · Consuelo A. Narváez-Vasquez • Joel González-Cabrera • \\ Diana Catalán Ruescas $\cdot$ Elisabeth Tabone $\cdot$ Jacques Frandon · Jeannine Pizzol • \\ Christine Poncet · Tomás Cabello $\cdot$ Alberto Urbaneja
}

Received: 12 March 2010/ Accepted: 11 June 2010/Published online: 8 July 2010

(c) Springer-Verlag 2010

\begin{abstract}
The tomato leafminer Tuta absoluta (Meyrick) (Lepidoptera: Gelechiidae) is a devastating pest of tomato originating from South America. After its initial detection in eastern Spain in 2006, it rapidly invaded various other European countries and spread throughout the Mediterranean basin. If no control measures are taken, then the pest can cause up to $80-100 \%$ yield losses in tomato crops in recently invaded areas and may pose a threat to both greenhouse and open-field tomato production. The exceptional speed and extent of $T$. absoluta invasion have called for studies documenting its biology and ecology, while indicating an urgent need for efficient and sustainable management methods. The development of approaches to manage T. absoluta would be facilitated through a detailed revision of information on this pest in its area of origin. This review combines information on the invasion by
\end{abstract}

Communicated by M. Traugott.

N. Desneux $(\bowtie) \cdot$ E. Wajnberg $\cdot$ E. Tabone $\cdot$ J. Pizzol ·

C. Poncet

INRA (French National Institute for Agricultural Research), 400 route des chappes, BP 167, 06903 Sophia-Antipolis, France e-mail: nicolas.desneux@sophia.inra.fr

K. A. G. Wyckhuys · C. A. Narváez-Vasquez

Horticulture Research Center, Universidad Jorge Tadeo Lozano,

Chia (Cundinamarca), Colombia

G. Burgio

Dipartimento di Scienze e Tecnologie Agroambientali-

Entomologia, Alma Mater Studiorum, Università di Bologna,

viale G. Fanin, 40127 Bologna, Italy

S. Arpaia

ENEA, National Agency for New Technology, Energy

and Economic Sustainable Development, Trisaia Research

Centre, S.S. 106 Jonica Km 419.5, 75026 Rotondella, Italy
T. absoluta, its ecology, and potential management strategies, including data that may help the implementation of efficient biological control programs. These programs, together with a variety of other management tactics, may allow efficient integrated pest management of $T$. absoluta in Europe and Mediterranean Basin countries.

Keywords Tuta absoluta . Biological control . Invasive species $\cdot$ Natural enemies .

Integrated pest management

\section{Introduction}

Invasive species represent a major threat to both natural (Clavero and García-Berthou 2005; Samways 2007) and agronomic (Olson 2006; Haack et al. 2010; Suckling and Brockerhoff 2010; Ragsdale et al. 2011) ecosystems.

\footnotetext{
J. González-Cabrera · A. Urbaneja

Instituto Valenciano de Investigaciones Agrarias (IVIA), Centro de Protección Vegetal y Biotecnología, Unidad de Entomología, Carretera Moncada-Náquera km 4,5, 46113 Moncada,

Valencia, Spain

D. Catalán Ruescas

Tecnologias y Servicios Agrarios, S. A., Tragsatec, C/Hnos.

Garcia Noblejas, 37C. 2a Planta, 280037 Madrid, Spain

J. Frandon

Biotop, 1306 route de Biot, 06560 Valbonne, France

T. Cabello

Centro de Investigación en Biotecnología Agroalimentaria,

Universidad de Almería, Ctra Sacramento s/n,

04120 Almería, Spain
} 
Agricultural pests can reduce yield, increase costs (related to their management), and lead to the use of pesticides which ultimately lead to the disruption of existing Integrated Pest Management (IPM) systems (Thomas 1999). The tomato leafminer Tuta absoluta (Meyrick) (Lepidoptera: Gelechiidae) is one of the most devastating pests of tomato in South America (Barrientos et al. 1998; Miranda et al. 1998). This pest was initially reported in eastern Spain in late 2006 (Urbaneja et al. 2007), and has subsequently spread throughout the Mediterranean Basin and Europe (Potting 2009). Since the time of its initial detection, the pest has caused serious damages to tomato in invaded areas (Germain et al. 2009), and it is currently considered a key agricultural threat to European and North African tomato production. Consequently, the ongoing invasion of $T$. absoluta has prompted applied research to undertake studies on many aspects of its biology and ecology. As T. absoluta has been a long-time pest of openfield and greenhouse tomato in South America (Vargas 1970; Fernández and Montagne 1990; Colomo et al. 2002), current European efforts could largely benefit from the knowledge that has been gathered on its biology, ecology and management in this part of the world.

In this article, first we provide basic information regarding $T$. absoluta biology in the Mediterranean countries and South America. Second, we review the history of invasion in Europe and Mediterranean Basin countries and assess the potential future spread of the pest throughout Europe. Third, we document T. absoluta's natural enemies in tomato crops in South America and their potential use for biological control within IPM schemes. Finally, we discuss costs and benefits for importing biological control agents of $T$. absoluta in the invaded areas.

\section{Tuta absoluta biology}

\section{Description}

Tuta absoluta (Lepidoptera: Gelechiidae) was originally described in 1917 by Meyrick as Phthorimaea absoluta, based on individuals collected from Huancayo (Peru). Later, the pest was reported as Gnorimoschema absoluta (Clarke 1962), Scrobipalpula absoluta (Povolny), or Scrobipalpuloides absoluta (Povolny), but was finally described under the genus Tuta as T. absoluta by Povolny in 1994 (Barrientos et al. 1998). Its life-cycle comprises four development stages: egg, larva, pupa and adult. Adults usually lay eggs on the underside of leaves or stems, and to a lesser extent on fruits. After hatching, young larvae penetrate leaves, aerial fruits (like tomato) or stems, on which they feed and develop. There are four larval stages. Fully-fed larvae usually drop to the ground on a silk thread and pupate in the soil, although pupation may also occur on leaves. Pupae (length: 5-6 mm) are cylindrical in shape and greenish when just formed becoming darker in colour as they are near adult emergence. Adults are $6-7 \mathrm{~mm}$ in length and present filiform antennae and silver to grey scales (Coelho and França 1987). Black spots are present on anterior wings, and the females are wider and more voluminous than the males.

The pest mainly presents nocturnal habits, and adults usually remain hidden during the day, showing greater morning-crepuscular activity with adults dispersing among crops by flying. Among a range of species within the Solanaceae, tomatoes (Lycopersicon esculentum Miller) appear to be the primary host of T. absoluta.

\section{Biology on tomato}

Tuta absoluta is multivoltine, and population parameters suggest that it is an r-selected species (Pereyra and Sánchez 2006). The duration of the developmental cycle greatly depends on environmental conditions, with average development time of 76.3 days at $14^{\circ} \mathrm{C}, 39.8$ days at $19.7^{\circ} \mathrm{C}$ and 23.8 days at $27.1^{\circ} \mathrm{C}$ (Barrientos et al. 1998). This research formed the basis for determination of temperature thresholds and thermal constants of $T$. absoluta. Temperature thresholds for egg, larva and pupa were estimated at $6.9 \pm 0.5,7.6 \pm 0.1$ and $9.2 \pm 1.0^{\circ} \mathrm{C}$, respectively; overall, the threshold for egg-larva-adult is $8.1 \pm 0.2^{\circ} \mathrm{C}$. Accordingly, thermal constants were $103.8 \pm 1.4,238.5 \pm$ 0.5 and $117.3 \pm 5.3 \mathrm{DD}$ for egg, larva and pupa, respectively, whereas the total thermal constant from egg to adult was estimated at $453.6 \pm 3.9$ DD. Larvae appear to refrain from entering diapause as long as food is available, and there can be 10-12 generations per year in South America. Vercher et al. (2010) were able to maintain T. absoluta larvae alive during several weeks at $4^{\circ} \mathrm{C}$. When $T$. absoluta does not pupate in the soil, a cocoon is usually built. Under Mediterranean conditions, adults of $T$. absoluta can be detected all around the year (Vercher et al. 2010). Adult lifespan ranges between 10 and 15 days for females and 6-7 days for males (Estay 2000). Females mate only once a day and are able to mate up to six times during their lifespan, with a single mating bout lasting $4-5 \mathrm{~h}$. The most prolific oviposition period is 7 days after first mating, and females lay $76 \%$ of their eggs at that time, with a maximum lifetime fecundity of 260 eggs per female (Uchôa-Fernandes et al. 1995).

\section{Secondary hosts}

Although T. absoluta prefers tomato, it can also feed, develop and reproduce on other cultivated Solanaceae such as egg plant (Solanum melongena L.), potato (S. tuberosum 
L.), sweet pepper (S. muricatum L.) and tobacco, Nicotiana tabacum L. (Vargas 1970; Campos 1976), as well as on non-cultivated Solanaceae (S. nigrum L., S. eleagnifolium L., S. bonariense L., S. sisymbriifolium Lam., S. saponaceum, Lycopersicum puberulum $\mathrm{Ph}$. etc.) and other naturally available host-plants such as Datura ferox L., D. stramonium L. and N. glauca Graham (Garcia and Espul 1982; Larraín 1986a). On potato, T. absoluta only attacks aerial parts, thereby not directly impeding tuber development. Nevertheless, leaf feeding may indirectly lower potato yield and, under appropriate climatic conditions, T. absoluta could become a pest for the potato crop (Pereyra and Sánchez 2006). Since the time of its arrival in Europe, additional plant species have been reported as alternative hosts. It has been reported in a Sicilian greenhouse of Cape gooseberry (Physalis peruviana) (Tropea Garzia 2009) and has been found in Italy on bean, Phaseolus vulgaris (EPPO 2009) and on Lycium sp. and Malva sp. (Caponero 2009). This indicates that T. absoluta shows a high propensity to use various plants as secondary hosts, notably species within the Solanaceae.

\section{Economic importance and current management}

\section{Economic importance in tomato}

In most countries of South America (Argentina, Bolivia, Brazil, Chile, Colombia, Ecuador, Paraguay, Peru, Uruguay and Venezuela) T. absoluta is considered a devastating pest of tomato (Barrientos et al. 1998; Estay 2000). Plants can be attacked at any developmental stage, with females ovipositing preferentially on leaves (73\%), and to lesser extent on leaf veins and stem margins (21\%), sepals $(5 \%)$ or green fruits (1\%) (Estay 2000). Oviposition was found possible on unripe tomatoes only (Monserrat 2009). After hatching, young larvae penetrate the leaves, stems or tomato fruits on which they feed and develop, creating conspicuous mines and galleries. In tomato leaves, damages are caused through mine-formation within the mesophyll by feeding larvae, thus affecting the plant's photosynthetic capacity and consequently lowering tomato yield. Galleries in stems alter the general development of the plant and could cause necrosis. Fruits can be attacked as soon as they are formed, and the galleries bored inside them can be invaded by secondary pathogens leading to fruit rot. Finally, an important additional problem is that the pest directly feeds on the growing tip, thereby halting plant development. The pest affects tomatoes destined to fresh market as well as to processing, with larvae causing losses in its area of origin of up to 80-100\% (Apablaza 1992; López 1991). Furthermore, feeding activity on fruits directly affects the visual aspect of harvested products.
Current management methods in South America

The primary T. absoluta management tactic in most South American countries is chemical control (Lietti et al. 2005). Organophosphates were initially used for $T$. absoluta control, which were gradually replaced by pyrethroids during the 1970s. During the early 1980s, cartap, which alternated with pyrethroids and thiocyclam, proved highly efficient in controlling pest outbreaks (Lietti et al. 2005). During the 1990s, novel insecticides were introduced, such as abamectin, acylurea IGR, spinosad, tebufonozide and chlorfenapyr. Recently in Brazil, 10 new molecules of pyrethroids proved to be effective in controlling $T$. absoluta, with different toxical effects, and in some cases, up to $100 \%$ larval mortality was recorded (Silvério et al. 2009). Also, some vegetal products were assessed for potential use in the leafminer control, including extracts of Trichilia pallens (da Cunha et al. 2006), species belonging to the same family of neem tree, whose extracts are largely used for insect pest control. However, the use of insecticide, drawing upon a limited set of products, has proven not to be a sustainable management option for this pest in South America. Since the 1980s, efficacy of organophosphates for T. absoluta control has gradually decreased in countries like Bolivia, Brazil and Chile (Salazar and Araya 1997; Siqueira et al. 2000, 2001). In addition, resistance development has been reported against organophosphates and pyrethroids in Chile (Salazar and Araya 1997) and against abamectin, cartap, methamidophos and permethrin in Brazil (Siqueira et al. 2000, 2001). Resistance to deltamethrin and abamectin has recently been demonstrated for open field and greenhouse populations of T. absoluta in Argentina (Lietti et al. 2005).

The decision scheme of using insecticides for management of $T$. absoluta is largely based on adult captures in sexual pheromone traps (Benvenga et al. 2007), as adult catches are correlated with larval damages and yield losses (Faccioli 1993; Benvenga et al. 2007). In Brazil, Benvenga et al. (2007) reported an action level of $45 \pm 19.50 \mathrm{~T}$. absoluta catched daily using pheromone traps, while in Chile extension specialists report an economic threshold of 100 males per pheromone trap per day. Action threshold could also be based on occurrence of the pest in the tomato crop with 2 females/plant or 26 larvae per plant (Bajonero et al. 2008) or 8\% defoliation (BayerCropScience, Colombia) recommended in Colombia. Mass trapping may also effectively remove sufficient males to lower overall $T$. absoluta population levels and reduce pest pressure (Witzgall et al. 2008, 2010). However, mass trapping would likely be most effective when used in conjunction with recommended insecticides. Other pest control approaches have been studied and documented, notably the potential use of biological control agents (predators, parasitoids and entomopathogens which are described in "Biological control of T. $a b$ soluta in South America" section), resistant plants (de Resende 
et al. 2006; Pereira et al. 2008; Campos et al. 2009; Oliveira et al. 2009; Maluf et al. 2010) and botanical insecticides (Moreira et al. 2004; da Cunha et al. 2005, 2006; GoncalvesGervasio and Vendramim 2007; da Cunha et al. 2008). However, despite increasing interest in such control approach options (notably because smaller populations of $T$. absoluta are usually observed in organic vs. conventional systems, Medeiros 2007; Medeiros et al. 2009b) they are only scarcely used.

\section{Assessing the invasion of Europe and Mediterranean Basin countries by $T$. absoluta}

The process of biological invasion can be divided into a series of phases: arrival, establishment and spread (Mack et al. 2002). Such an iterative process is employed to quantify the likelihood and impact of invasion by an exotic pest species in a new geographic region, and could constitute a suitable framework for assessing the invasion of T. absoluta in Europe and Mediterranean Basin countries.

\section{Arrival}

\section{Geographic range before invasion of Mediterranean Basin countries}

Tuta absoluta is thought to be native from South America, and it was originally described in Peru (Luna MG, personal com.). Since the early 1980s, it is recorded as a pest in Argentina, Bolivia, Brazil, Chile, Colombia, Ecuador, Paraguay, Peru, Uruguay and Venezuela (Barrientos et al. 1998; Estay 2000). The species is usually found under open-field conditions up till $1000 \mathrm{~m}$ above sea level, but it has been observed in greenhouse and open-field tomato crops in Colombia at 2600 and $1900 \mathrm{~m}$, respectively (Wyckhuys KAG, personal obs.); the holotype was collected in Peru at $3500 \mathrm{~m}$ (Povolny 1975). Tuta absoluta is thought to have benefited greatly from agricultural trade within the continent for its further spread (Cáceres 1992). For example, agricultural trade between Chile and Argentina introduced T. $a b$ soluta to the Mendoza province (Argentina) in 1964 (Bahamondes and Mallea 1969). Before its arrival in Europe, T. absoluta was exclusively reported from South America and Easter Island (Ripa et al. 1995), although there is an unconfirmed record of this pest attacking Solanum lyratum in Japan (Clarke 1962). Given that no recent records are available in Japan, it may either not have established or this record is from a misidentification.

\section{Interceptions and measures against expansion}

Despite its initial denomination as a key quarantine pest (i.e. A1 listing in 2004; EPPO 2005), T. absoluta was-and still is-not listed in Plant Health Directive 2000/29/EC. Consequently, tomato fruits originating in third countries were not subject to a plant health inspection before their entry and movement within the European Community. This omission could have caused the introduction of T. absoluta into Europe, which was reported from the province of Castellón de la Plana (eastern Spain) in late 2006 (Urbaneja et al. 2007). Based on experiences in South America, spread of T. absoluta can be greatly facilitated through agricultural trade. Despite the presence of well-organized plant protection agencies throughout Europe, contingency measures are proving ineffective to halt the spread of $T$. absoluta throughout the continent. For example, despite recurrent interceptions of T. absoluta by the British Food and Environment Research Agency (FERA) from 2006 to 2009, subsequent intensive monitoring of tomato packing stations and statutory control measures at infested sites, the pest was ultimately reported from a tomato farm in the British countryside in July 2009. Similarly, The Netherlands Plant Protection Service recorded T. absoluta in a tomato packaging and sorting facility in 2008 (Potting 2009) and the Russian Phytosanitary Service reported the presence of T. absoluta in the Kaliningrad region in tomato shipments from Spain. All the above clearly indicate that $T$. absoluta can be introduced into new countries of Europe and Mediterranean Basin countries by means of tomato fruits from infested areas. However, in short/medium distances, natural spread seems to be the major risk. The spread of the pest in Spain is mainly happening by natural means (Spanish Expert Group in Plant Protection of Horticultural Crops, personal communication). Wind currents seem to be especially favourable for its dispersal (though the flight ability of $T$. absoluta remains as an uncertainty, which should be studied further). The US Department of Agriculture's (USDA) Animal and Plant Health Inspection Service (APHIS) is constantly updating the list of countries whose imported products are regulated for T. absoluta. Federal Orders were issued in February and May 2009 (Bech 2009) that place severe restrictions on tomato fruits from infested countries (Albania, Algeria, France, Greece, Italy, Morocco, Netherlands, Portugal, Spain, Switzerland and Tunisia). USDA-APHIS also prohibits the entry of Solanum sp., Datura spp. and Nicotiana spp., as potential host plants of T. absoluta from all of the above mentioned countries, pending the completion of a Pest Risk Analysis and implementation of appropriate mitigation measures. Spain is currently authorized to export green, pink and red tomatoes to the USA provided that a system approach to mitigate the risk associated with $T$. absoluta is applied. This requirement is in accordance with the temporary emergency measures for the control of $T$. absoluta established by the Spanish Plant Protection Committee and which have been adopted by all the Spanish Autonomous Regions (Table 1). 
Table 1 Main guidelines of the measures to control Tuta absoluta adopted in Spain (Spanish Plant Protection Committee)

\begin{tabular}{|c|c|}
\hline Measures & Means \\
\hline Detection & $\begin{array}{l}\text { Pheromone traps in sites of production and } \\
\text { warehouses }\end{array}$ \\
\hline Cultural measures & $\begin{array}{l}\text { Removal of crop residues, cultivation } \\
\text { restrictions if the pest is detected, physical } \\
\text { isolation of greenhouses and warehouses }\end{array}$ \\
\hline Control measures & $\begin{array}{l}\text { Biological control, massive trapping and } \\
\text { chemical or microbiological treatments with } \\
\text { authorized products in crops }\end{array}$ \\
\hline Registration & $\begin{array}{l}\text { Records of traps, captures, treatment schedules } \\
\text { and active ingredients applied }\end{array}$ \\
\hline $\begin{array}{l}\text { Official inspections } \\
\text { Monitoring }\end{array}$ & $\begin{array}{l}\text { Monitoring on production sites, crops and } \\
\text { warehouses throughout the growing season to } \\
\text { ensure that fruit is produced and packed free of } \\
\text { larvae of } T \text {. absoluta }\end{array}$ \\
\hline $\begin{array}{l}\text { Protection in } \\
\text { transit/storage }\end{array}$ & Insect-proof containers or mesh \\
\hline
\end{tabular}

Establishment and spread

\section{Invasion and geographic range in the new area}

In 2007, T. absoluta was detected in several greenhouses of the Spanish Mediterranean Basin, causing serious damages to tomato. In the subsequent growing season, the pest was reported from tomato in all the main coastal areas of Spain, and $T$. absoluta populations reached damaging levels at multiple locations in the Mediterranean coast. In 2008 and 2009, T. absoluta was reported in tomato crops from Italy, southern France, Greece, Portugal, Morocco, Algeria and Tunisia (Potting 2009). In 2008, T. absoluta was reported from five principal tomato-growing regions (i.e., Liguria, Sicilia, Sardegna, Calabria, Campania), while in 2009 T. absoluta further invaded central and northeast Italy. This pest was occasionally found in mixed populations with another invasive Gelechiid moth: Keiferia lycopersicella (Walshingham) (Sannino and Espinosa 2009). In France, T. absoluta was originally found during late 2008 on Corsica island and in various areas of the French Riviera, and further expanded its geographic distribution in 2009 to north (Rhône-Alpes) and southwest (Languedoc-Roussillon) (Germain et al. 2009) and recently to two regions of the Atlantic coast (Decoin 2010). In Greece, in 2009, the species was present in the mainland (Prevesa, Axaia, Trifilia) and Crete (Roditakis et al. 2010). The pest was initially reported from several locations of Portugal in 2009. In addition, $T$. absoluta has been reported in some European countries with colder climate (Switzerland, UK and the Netherlands); such phenomenon, though, is considered to be confined to the protected tomato cultivation (Potting 2009). Finally, the presence of this pest has been reported in southern Germany and Cyprus (EPPO 2010), in tomato greenhouses in Romania, in both greenhouse and openfield tomato crops in Bulgaria (EC Report 2009), in Turkey (Kılıç 2010), in Lithuania and in Middle East (Bahrain, Kuwait) (Fig. 1).

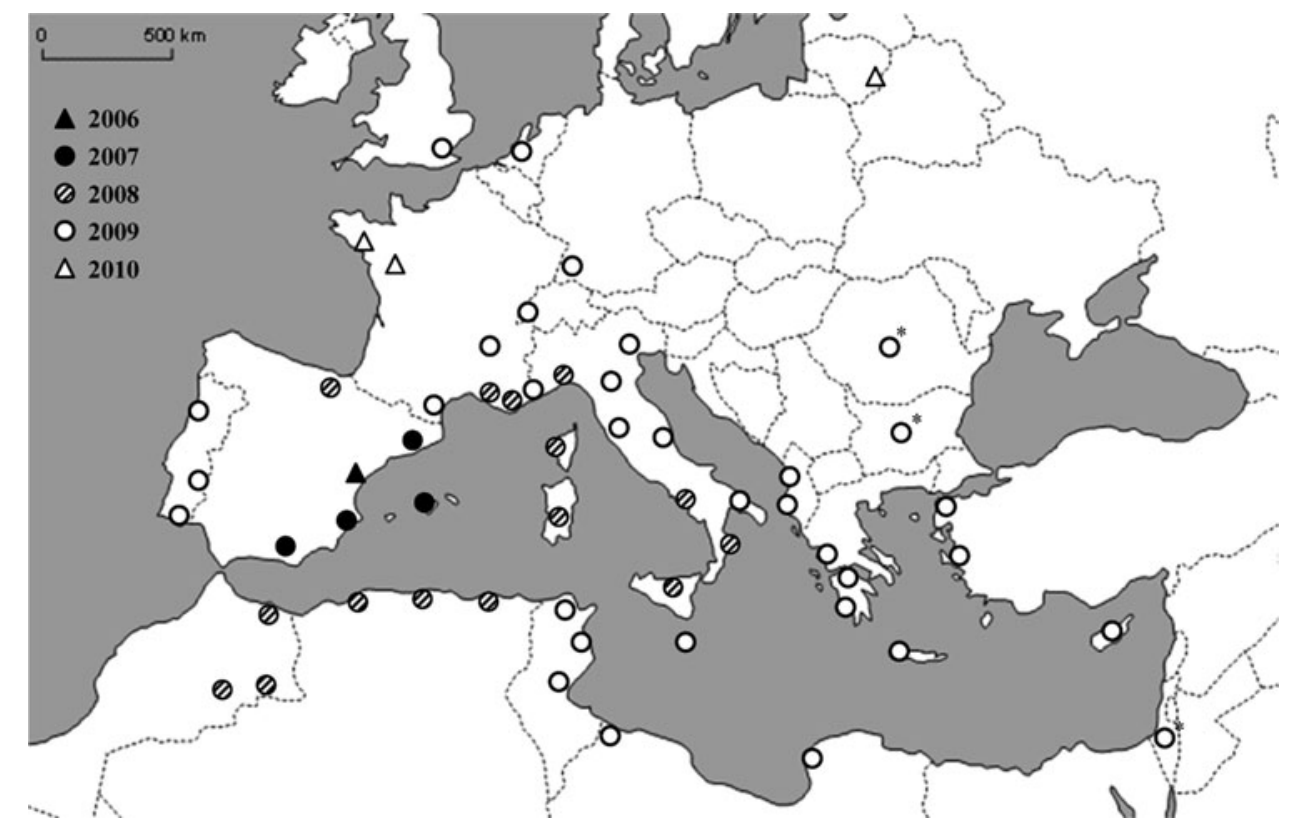

Fig. 1 Years in which Tuta absoluta was first detected in different areas of Mediterranean and European countries. The information provided is based on a compilation of reports from plant protections services of T. absoluta-invaded countries and from the European and
Mediterranean Plant Protection Organization (EPPO). * Countries where the pest has been reported without precise geographic localization 


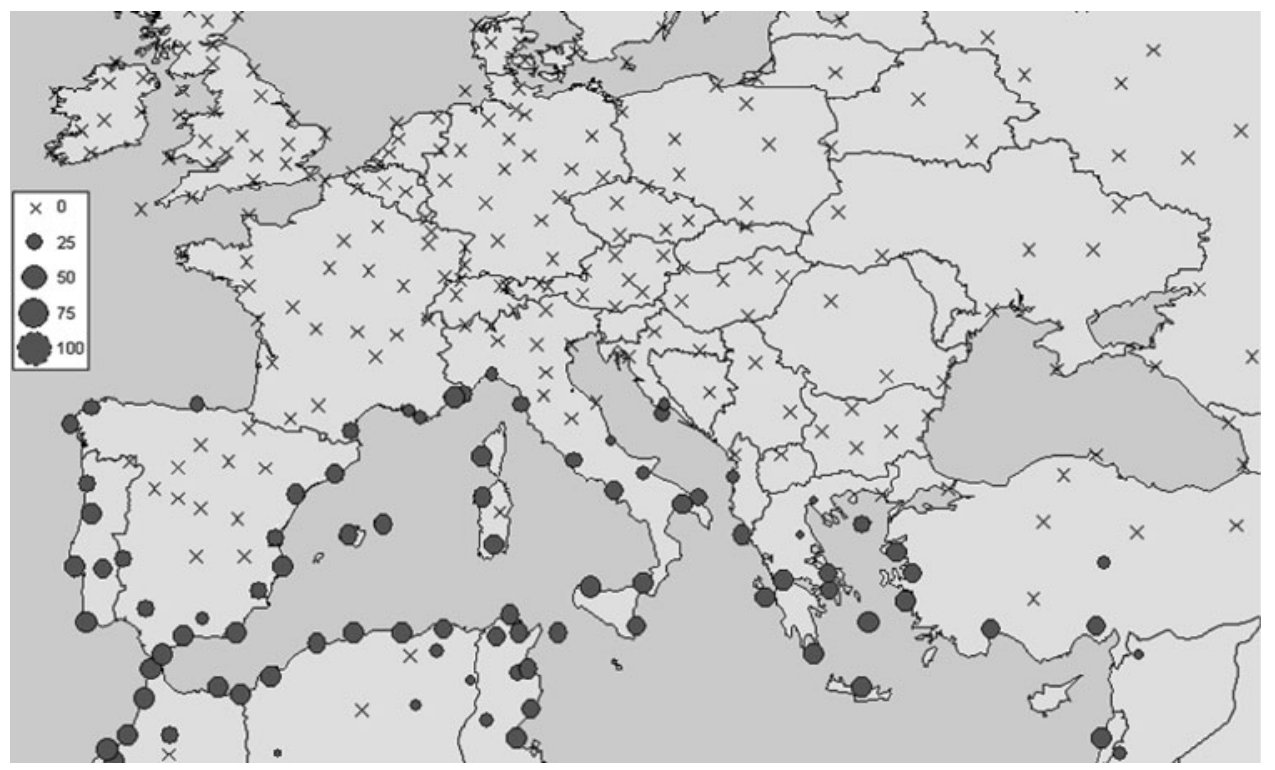

Fig. 2 The predicted distribution Ecoclimatic Index (EI) of Tuta absoluta in Europe and North African countries. The dots represent EI values with increasing dots' size indicating higher EI values. The higher the EI value, the more suitable the climate at that location (EI 10: species could survive, 30: very favourable, Sutherst et al. 2007). Biological parameters of T. absoluta used in the model are from Marcano (1995), Betancourt et al. (1996) and Barrientos et al. (1998). The potential distribution of T. absosulta is based both on its establishment in Europe (in the early 2008) and its presence in South America. Information from South America were included (more than 150 locations from Argentina, Bolivia, Brazil, Chile, Colombia, Ecuador, Paraguay, Peru, Uruguay and Venezuela were used during

\section{Climatic similarity}

Climatic comparison is a useful tool for evaluating where the introduced species might become established within a new geographic region (Mack et al. 2002). The Mediterranean Basin area presents similar climatic conditions to areas where T. absoluta occurs in South America, particularly the southern part of Brazil, Uruguay, most of Argentinean territories and part of Chile. In particular, low temperatures constitute limiting factors for $T$. absoluta survival (Notz 1992). The establishment of the species at higher latitudes, however, is considered unlikely in Europe (Potting 2009). Based on the calculation of ecoclimatic indexes, a map of suitability of the Mediterranean basin climates for the establishment of $T$. absoluta in field conditions has been drawn (Fig. 2). The actual distribution of the pest (Fig. 1) indicates that the estimate based on climatic indexes might be too conservative and the geographical range of the species in Europe could be larger than expected. However, it must be highlighted that neither protected cultivation nor transient populations are considered in the Climex model. Therefore, in Northern Europe the pest may not survive in the field throughout the year, the parameter fitting process). Parameters used in Climex model: moisture index: $\mathrm{SM} 0=0.1, \mathrm{SM} 1=0.4, \mathrm{SM} 2=0.7, \mathrm{SM} 3=2$; temperature index: $\mathrm{DV} 0=8, \mathrm{DV} 1=20, \mathrm{DV} 2=25, \mathrm{DV} 3=35$; cold Stress: TTCS $=3$, THCS $=-0.001$, DTCS $=15$, DHCS $=$ $-0.001, \quad$ TTCSA $=0, \quad$ THCSA $=0 ;$ heat Stress: TTHS $=35$, THHS $=0.0015$, DTHS $=0$, DHHS $=0$; dry Stress: SMDS $=0.1$, HDS $=-0.01$; wet Stress: SMWS $=2$, HWS $=0.002$; day degree accumulation above DVO: $\mathrm{DVO}=8, \mathrm{DV} 3=35$, MTS $=7$; day degree accumulation above DVCS: $\mathrm{DVCS}=8$, DV4 $=100$; day degree accumulation above DVHS: DVHS $=35$; degree-days per generation: $\mathrm{PDD}=460$

but it may occur during suitable periods, i.e. the summer months. Also, it may be able to establish permanent populations inside greenhouses if hosts are available throughout the year.

\section{Potential for future spread}

Tomato is thought to be the most suitable host plant for T. absoluta and has a better nutritional quality than potato (Pereyra and Sánchez 2006), and tomato cultivation could be a determining factor for $T$. absoluta establishment in Europe and Mediterranean Basin countries. Nine Mediterranean countries (i.e. Turkey, Egypt, Italy, Spain, Greece, Morocco, Portugal, Tunisia, Algeria) are considered key tomato producers (data 2008, United Nations, Food and Agriculture Organization data), thereby providing a potential huge food resource for T. absoluta in the region. Moreover, the presence of greenhouse crops can significantly extend seasonal availability of a preferred host in regions with temperate climates (like in northern Europe). Current establishment patterns of T. absoluta highlight the importance of tomato. In addition to potatoes which are known hosts for T. absoluta (Campos 1976; 
Cisneros and Mujica 1998), particular attention should be given to leguminous plants as alternative hosts for this pest as these plants have a relatively long cropping season compared to Solanaceae. If T. absoluta continues to expand its host range to this plant family, then its spread through Europe may not only be restricted to tomato-producing regions. Current literature lacks studies providing data on T. absoluta population growth on alternative hosts (notably on weeds found throughout Europe). As indicated above, intra-European trading of tomato appears to be the current primary means of geographic long range spread of this pest. Nevertheless, as certain lepidopteran species have considerable active dispersal capacity (Chen et al. 1989; Fitt 1989; Feng et al. 2005), this species likely also colonize new areas through (active) flight or (passive) reliance on wind currents.

\section{Potential for effective biological control of T. absoluta in the Mediterranean basin}

Since its arrival in the Mediterranean Basin, a set of endemic natural enemies have been reported on $T$. absoluta, and their suitability for T. absoluta biological control is currently being evaluated.

A number of parasitoids have been found to be in association with $T$. absoluta at several locations in the Mediterranean basin (Table 2). The parasitoids Necremnus artynes (Walker) and Hemiptarsenus zilahisebessi Erdös (Hymenoptera: Eulophidae) have occurred spontaneously in infested tomato plots in Spain (Mollá et al. 2008; Gabarra and Arnó 2010). In the case of $N$. artynes, its field abundance has considerably increased from 2008 to 2009. This is an idiobiont ectoparasitoid, and it seems parasitizing preferentially third instar larvae of T. absoluta. Recent reports of various undetermined species (mainly Braconidae) attacking T. absoluta along the Mediterranean Coast (Mollá et al. 2008; Arnó et al. 2009) may indicate that local parasitoids are gradually adapting to this newly arrived pest. It can equally be expected that the native egg parasitoid Trichogramma achaeae Nagaraja \& Nagarkatti (Hymenoptera: Trichogrammatidae) steadily develops a search profile or parasitism preference for T. absoluta (Cabello et al. 2009b). Pilot experiments showed $T$. achaeae to be highly efficient in lowering $T$. absoluta infestation levels in experimental and commercial tomato greenhouses in southern Spain (Cabello et al. 2009b). More specifically, release of T. achaeae at a rate of 750,000 adults ha ${ }^{-1}$ every 3 or 4 days significantly reduced the number of $T$. absoluta larvae, leaf mines and damaged fruits, compared to control plots. This egg parasitoid appears to be particularly promising for T. absoluta when used in combination with mirid predators (Fig. 3). Based on these findings, T. achaeae has become commercially available for augmentation biological control, with a recommended release dose of 250,000500,000 adults $\mathrm{ha}^{-1}$ per week, according to the level of the

Table 2 Natural enemies reported in the Mediterranean Basin on Tuta absoluta

\begin{tabular}{|c|c|c|c|c|}
\hline Order & Family & Species & Stage prefered & References \\
\hline \multicolumn{5}{|l|}{ Parasitoids } \\
\hline \multirow[t]{5}{*}{ Hymenoptera } & \multirow[t]{2}{*}{ Eulophidae } & Necremnus artynes (Walker) & $\mathrm{L}_{2}-\mathrm{L}_{3}$ & $\begin{array}{l}\text { Mollá et al. (2008), Gabarra } \\
\text { and Arnó (2010) }\end{array}$ \\
\hline & & Hemiptarsenus zilahisebessi Erdös & $\mathrm{L}_{2}-\mathrm{L}_{3}$ & Gabarra and Arnó (2010) \\
\hline & Braconidae & Braconidae sp. & - & $\begin{array}{l}\text { Gabarra and Arnó (2010), } \\
\text { Mollá et al. (2010) }\end{array}$ \\
\hline & \multirow[t]{2}{*}{ Trichogrammatidae } & $\begin{array}{l}\text { Trichogramma achaeae Nagaraja } \\
\text { \& Nagarkatti }\end{array}$ & Eggs & Cabello et al. (2009b) \\
\hline & & Trichogramma sp. & Eggs & $\begin{array}{l}\text { Gabarra and Arnó (2010), } \\
\text { Mollá et al. (2010) }\end{array}$ \\
\hline \multicolumn{5}{|l|}{ Predators } \\
\hline \multirow[t]{4}{*}{ Hemiptera } & \multirow[t]{3}{*}{ Miridae } & Nesidiocoris tenuis Reuter & Eggs and young larvae & $\begin{array}{l}\text { Arnó et al. (2009), Mollá et al. (2009), } \\
\text { Urbaneja et al. (2009) }\end{array}$ \\
\hline & & Macrolophus pygmaeus (Rambur) & Eggs and young larvae & $\begin{array}{l}\text { Arnó et al. (2009), Mollá et al. (2009), } \\
\text { Urbaneja et al. (2009) }\end{array}$ \\
\hline & & Dicyphys marrocannus Wagner & Eggs and young larvae & Mollá et al. (2010) \\
\hline & Nabidae & $\begin{array}{l}\text { Nabis (Nabis) pseudoferus ibericus } \\
\text { Remane }\end{array}$ & Larvae and larvae & Cabello et al. (2009a) \\
\hline Hymenoptera & Vespidae & Undeterminated species & Larvae & Mollá et al. (2008) \\
\hline \multirow[t]{2}{*}{ Acari } & \multirow[t]{2}{*}{ Phytoseiidae } & Amblyseius swirskii Athias-Henriot & Eggs (on aubergine) & Mollá et al. (2010) \\
\hline & & Amblyseius cucumeris (Oudemans) & Eggs (on aubergine) & Mollá et al. (2010) \\
\hline
\end{tabular}




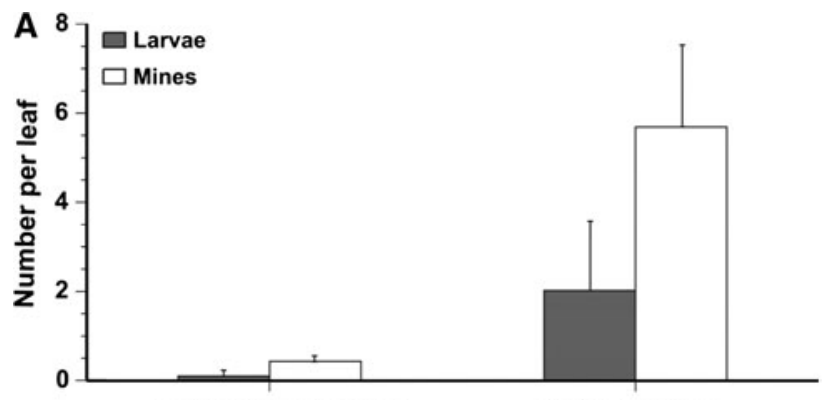

T. achaeae $+N$. tenuis

N.tenuis alone

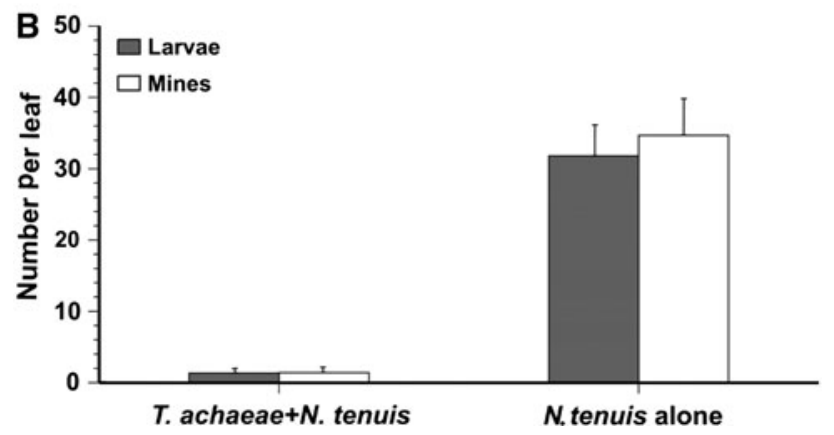

Fig. 3 Impact of inundative releases of the egg parasitoids Trichogramma achaeae used in combination with the predator Nesidiocoris tenuis on Tuta absoluta population dynamics in experimental tomato greenhouses (Experimental Station Foundation Cajamar, El Ejido, Almeria, Spain). The greenhouse was separated in two sections, and each part was initially infested by T. absoluta (four adults per plant). In the first sections, adults of the predator, $N$. tenuis, were released (one individual per plant) in combination with release of $T$. achaeae adults (50 individuals $\mathrm{m}^{-2}$, two times a week, only the first 10 weeks of crop cycle: 01 March to 31 July 2009). In the second section, only $N$. tenuis adults were released. After 40 days (a: first pest generation) and 69 days (b: second pest generation) the number of $T$. absoluta larvae and mines $( \pm$ SEM) per leaf were significantly lower in section 1 (T. achaeae $+N$. tenuis) than in section 2 ( N. tenuis alone) for both T. absoluta generation considered (Anova results: first generation larvae: $F_{47}=20.70, P<0.01$; first generation mine: $F_{47}=33.28$, $P<0.01$; second generation larvae: $F_{47}=74.46, P<0.01$; second generation mine: $F_{47}=70.45, P<0.01$; Cabello T. and Vila E., unpublished data)

pest infestation. For field use, T. achaeae is mass-reared on Ephestia kuehniella Zeller (Lepidoptera: Pyralidae) eggs, and parasitized eggs are distributed to growers in userfriendly dispensers. The use of $T$. achaeae is recommended at the onset of the tomato-growing cycle, when T. absoluta predators are not yet well established in tomato fields. Recent data, however, show that $T$. achaeae mass releases for $T$. absoluta control may not be economically sustainable, and that parasitoid releases should be combined with other biological control methods.

Within the first year of its arrival in the Mediterranean region, a fair number of arthropod predators were reported from T. absoluta (Table 2). Predation potential and life history aspects of Macrolophus pygmaeus and Nesidiocoris tenuis (on T. absoluta) has been tested under laboratory
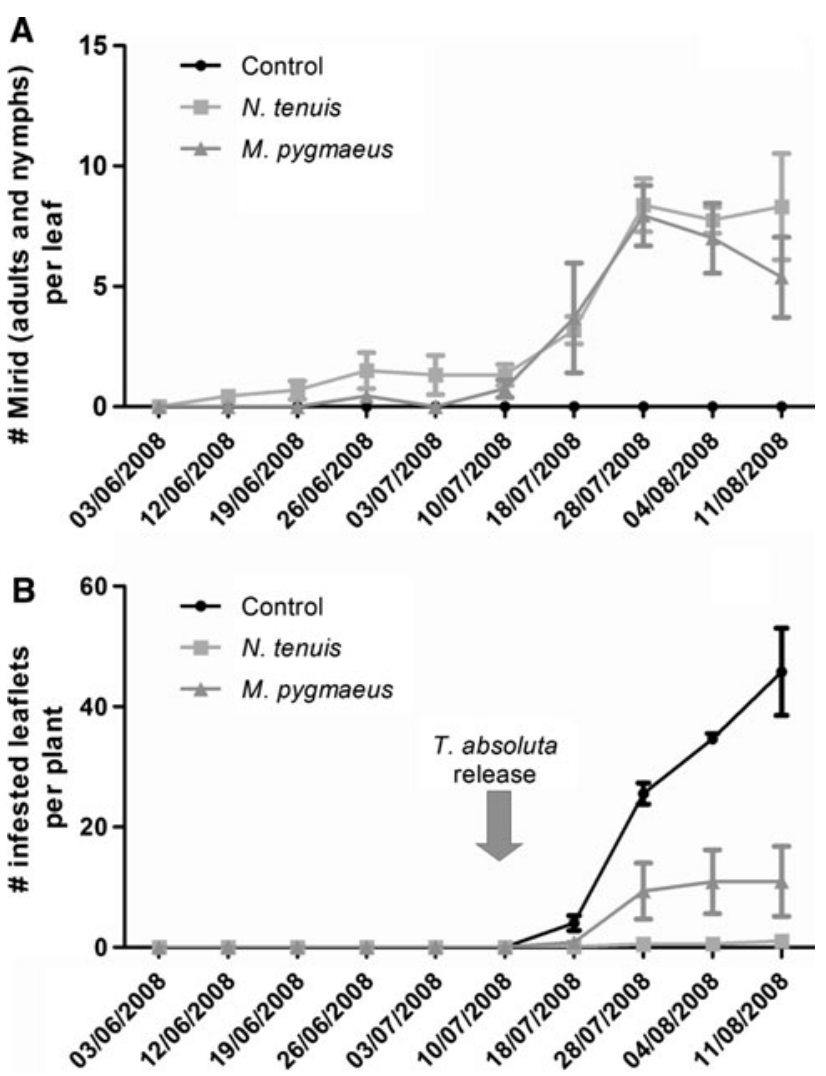

Fig. 4 a Mean number $( \pm$ SEM) of mirid (adults + nymphs) per leaf and $\mathbf{b}$ mean number ( \pm SEM) of $T$. absoluta infested leaflets per plant in an experimental tomato greenhouse located at Moncada, Valencia (Spain). Under these experimental conditions (summer 2008) and when both mirid species, $N$. tenuis and M. pygmaeus, were installed in the crop, $N$. tenuis was highly effective controlling $T$. absoluta with reductions of up $97 \%$ of leaflet and of $100 \%$ of fruits. Macrolophus pygmaeus was also effective, although its efficacy was lower in comparison to $N$. tenuis (76 and $56 \%$ reductions of leaflet and fruit infestation) (adapted from Mollá et al. 2009)

conditions (Arnó et al. 2009; Mollá et al. 2009; Urbaneja et al. 2009). Both predators actively attack $T$. absoluta eggs and larval stages, although they prefer first-instar larvae. Adults of both species consumed $>100$ eggs per individual per day, and M. pygmaeus nymphs consumed less T. absoluta eggs than $N$. tenuis nymphs (Arnó et al. 2009). Mollá et al. (2009) showed that when M. pygmaeus and $N$. tenuis were well established in the crop, they were able to reduce leaflets infestation up to 75 and $97 \%$ or fruits infestation up to 56 and $100 \%$, respectively (Fig. 4). Arnó et al. (2009) based on 281 different field observations (greenhouse and open tomato fields), established that when an average 4.5 mirids were present per plant, the level of fruit damage remained below $4 \%$, terming both mirid species as effective natural enemies of this pest. Since a good mirid establishment is needed to guarantee efficacy on T. absoluta, Calvo et al. (2010) advanced the N. tenuis release at nursery stage. Just after planting a good mirid 
establishment was obtained with this strategy, which resulted highly efficient controlling both, T. absoluta and whiteflies.

Apart from different mirid species, predatory mites, such as Amblyseius swirskii Athias-Henriot and Amblyseius cucumeris (Oudemans) (Acari: Phytoseiidae) are considered promising T. absoluta egg predators, notably on aubergine for which $T$. absoluta could become a pest (Urbaneja A, unpublished data).

In the Mediterranean Basin, promising results were obtained with Bt-based formulations in laboratory, greenhouse and open staked-tomato field in Valencia (Spain) (González-Cabrera et al. accepted). All commercial formulates tested reduced T. absoluta damage up to $90 \%$ when sprayed at $180.8 \mathrm{MIU} / \mathrm{l}$ (Millions of International Units per litre), while greenhouse assays show that even weekly Bt sprays at $90.4 \mathrm{MUI} / \mathrm{l}$ can control T. absoluta throughout the growing season. Entomopathogenic fungi, such as Beauveria bassiana, may be promising agents for control of $T$. absoluta in open tomato fields, eventually in combination with Bt sprays (Torres Gregorio et al. 2009). However, further experiments are needed to define how to optimally integrate B. bassiana and Bt sprays to control T. absoluta (preventive treatments with Bt showed low persistence, Monserrat 2009, 2010).

\section{Biological control of T. absoluta in South America}

Apart from the seminal research of Polack (2007), comprehensive revisions of $T$. absoluta biological control are scarce. Here, we describe key arthropod natural enemies, the respective susceptible $T$. absoluta developmental stages, as well as the geographical localities where the presence of natural enemies has been documented along with potential pathogens of T. absoluta in South America.

\section{Insect parasitoids}

During the past decades, surveys have been conducted of the T. absoluta natural enemy complex in a number of South American countries (Vargas 1970; Oatman and Platner 1989; Uchôa-Fernandes and Campos 1993; Colomo et al. 2002; Marchiori et al. 2004; Colomo and Berta 2006). A broad variety of parasitoids have been reported attacking egg, larval or pupal stages of T. absoluta (Table 3). Some species appear restricted to a given locality or country while other species are broadly distributed in South America.

Reports of multiple species of egg parasitoids, belonging to the families Encyrtidae (Ripa et al. 1995; Colomo et al. 2002), Eupelmidae (Oatman and Platner 1989) or Trichogrammatidae (Botto et al. 2000; Colomo et al. 2002) exist in the literature. The Trichogramma species complex associated with T. absoluta is diverse, with records of minimum 10 species throughout South America (Table 3). For several Trichogramma species, mass-rearing programs have been set up and parasitoids are readily used in inundative biological control. Biological control of T. absoluta using Trichogramma spp. is documented in Argentina (Botto et al. 2000; Riquelme and Botto 2003), Brazil (Villas Bôas and Franca 1996; Haji 1997, 2002; Parra and Zucchi 2004), Colombia (Navarro 1986; Vallejo 1999) and Chile (Estay and Bruna 2002). The following species have been mass-reared successfully: T. nerudai (Argentina: Tezze and Botto 2004; Cáceres 2007; Chile: Delbene 2003; Gerding and Torres 2003), T. bactrae (Argentina: Riquelme and Botto 2003; Chile: Delbene 2003), T. pretiosum (Colombia: Vallejo 1999; Brazil: Pratissoli et al. 2005; Chile: Delbene 2003) and T. exiguum (Colombia: Vallejo 1999), while laboratory cultures of $T$. pretiosum are maintained in various countries for experimental purposes (e.g. Berti and Marcano 1995). Promising species such as $T$. bactrae and T. nerudai are currently under evaluation for T. absoluta control in Argentina (Cáceres 2007). Using inundative releases of T. exiguum as part of a more comprehensive IPM strategy, parasitism levels reached 9.8$28.6 \%$ in open-field tomato in Colombia (Salas 2001). In Brazil, $87 \%$ parasitism of $T$. absoluta by $T$. pretiosum is reported from greenhouses (Parra and Zucchi 2004), and integration with Bacillus thuringiensis applications has proven both as technically viable and economically efficient pest control strategy in local greenhouse tomato (Medeiros et al. 2009a). On the other hand, trials with periodic releases of $T$. pretiosum in Chile have proven unsuccessful, with parasitism between 1.5 and $6.7 \%$ in open-field and greenhouse tomato (Jimenez et al. 1998; Taco et al. 1998). Actual success with T. pretiosum in Brazil has been the result of rigorous agent selection (Pratissoli and Parra 2000, 2001; Pratissoli et al. 2005). A few of the Trichogramma spp., efficient or promising for the control of $T$. absoluta, have been moved extensively among South American countries, occasionally as part of classical biological control schemes. For example, T. pretiosum was introduced in Chile and released in different tomato production regions of the country (Ripa et al. 1995; Lavandero et al. 2006), and was also introduced into Paraguay (Benitez 2000). As early as $1965, T$. minutum was collected in Peru for use against T. absoluta in Chile (Klein Koch 1977), while in 1973 T. pintoi was shipped to Peru for control of this pest (Whu and Valdivieso 1999). However, the level of control attained by many of those introductions remained undocumented (e.g., Klein Koch 1977).

Aside from egg parasitoids, a diverse community of larval parasitoids has been recorded on T. absoluta, including species of Bethylidae, Braconidae, Eulophidae, Ichneumonidae and Tachinidae (Table 3). Especially Braconidae 
Table 3 Parasitoids associated with different developmental stages of Tuta absoluta in South America ( $E$ egg, $L$ larvae, $P$ pupae, $A$ adult)
Countries with a given parasitoid from $T$. absoluta are indicated (A Argentina, $\mathrm{Br}$ Brazil, $\mathrm{Cl}$ Chile, Co Colombia, $P$ Peru, $P a$

Paraguay, $V e$ Venezuela). By no means has the listing been intended to be exhaustive, and its elaboration was based on the available literature sources only

\begin{tabular}{|c|c|c|c|c|c|c|c|}
\hline \multirow[t]{2}{*}{ Order } & \multirow[t]{2}{*}{ Family } & \multirow[t]{2}{*}{ Species } & \multicolumn{4}{|c|}{$\begin{array}{l}\text { T. absoluta } \\
\text { susceptible stage }\end{array}$} & \multirow[t]{2}{*}{ Location } \\
\hline & & & $\mathrm{E}$ & $\mathrm{L}$ & $\mathrm{P}$ & A & \\
\hline \multirow[t]{49}{*}{ Hymenoptera } & Bethylidae & Goniozus nigrifemur & - & $X$ & - & - & $\mathrm{Br}, \mathrm{Co}$ \\
\hline & Braconidae & Agathis sp. & - & $\mathrm{X}$ & - & - & A \\
\hline & & Apanteles sp. & - & $\mathrm{X}$ & $\mathrm{X}$ & - & Co \\
\hline & & Apanteles dignus & - & $\mathrm{X}$ & - & - & Co \\
\hline & & Apanteles gelechiidivoris & - & $\mathrm{X}$ & - & - & $\mathrm{Co}, \mathrm{Cl}, \mathrm{P}$ \\
\hline & & Bracon sp. & - & $\mathrm{X}$ & - & - & $\mathrm{Br}, \mathrm{Co}$ \\
\hline & & Bracon lucileae & - & $\mathrm{X}$ & - & - & $\mathrm{A}, \mathrm{Br}, \mathrm{Co}$ \\
\hline & & Bracon lulensis & - & $X$ & - & - & A \\
\hline & & Bracon tutus & - & $\mathrm{X}$ & - & - & A \\
\hline & & Chelonus sp. & - & $X$ & - & - & $\mathrm{A}, \mathrm{Br}$ \\
\hline & & Earinus sp. & - & $\mathrm{X}$ & - & - & $\mathrm{A}, \mathrm{Br}$ \\
\hline & & Orgilus sp. & - & $X$ & - & - & A \\
\hline & & Pseudapanteles dignus & - & $\mathrm{X}$ & - & - & $\mathrm{A}, \mathrm{Cl}$ \\
\hline & Chalcididae & Conura sp. (syn Spilochalcis sp.) & - & - & $X$ & - & $\mathrm{A}, \mathrm{Br}$ \\
\hline & & Invreia sp. & - & - & $\mathrm{X}$ & - & Co \\
\hline & Encyrtidae & Arrhenophagus sp. & $\mathrm{X}$ & - & - & - & $\mathrm{Br}$ \\
\hline & & Copidosoma sp. & $\mathrm{X}$ & - & - & - & A \\
\hline & & Copidosoma desantisi & $\mathrm{X}$ & - & - & - & $\mathrm{Cl}$ \\
\hline & & Copidosoma koehleri & $\mathrm{X}$ & - & - & - & $\mathrm{Cl}$ \\
\hline & Eulophidae & Chrysonotomyia sp. & - & $\mathrm{X}$ & - & - & $\mathrm{Ve}$ \\
\hline & & Clostrocerus formosus & - & $\mathrm{X}$ & - & - & A \\
\hline & & Dineulophus phthormiaeae & - & $\mathrm{X}$ & - & - & $\mathrm{A}, \mathrm{Cl}$ \\
\hline & & Horismenus sp. & - & $\mathrm{X}$ & $\mathrm{X}$ & - & $\mathrm{Br}$ \\
\hline & & Elasmus sp. & - & $\mathrm{X}$ & $\mathrm{X}$ & - & Co \\
\hline & & Neochrysocharis formosa & - & $\mathrm{X}$ & - & - & A \\
\hline & & Retisympiesis phthorimaea & - & $\mathrm{X}$ & - & - & $\mathrm{Cl}$ \\
\hline & & Sympiesis sp. & - & $\mathrm{X}$ & - & - & Co \\
\hline & & Tetrastichus sp. & - & $X$ & - & - & Co \\
\hline & & Zagrammosoma sp. & - & $\mathrm{X}$ & - & - & $\mathrm{Ve}$ \\
\hline & Eupelmidae & Anastatus sp. & $X$ & - & - & - & $\mathrm{Co}$ \\
\hline & Ichneumonidae & Campoplex haywardi & - & $\mathrm{X}$ & - & - & A \\
\hline & & Diadegma sp. & - & $\mathrm{X}$ & - & - & $\mathrm{A}, \mathrm{Br}, \mathrm{Co}$ \\
\hline & & Pristomerus sp. & - & $X$ & - & - & Co \\
\hline & & Temelucha sp. & - & $\mathrm{X}$ & - & - & A, Co \\
\hline & Tachinidae & Archytas sp. & - & $\mathrm{X}$ & - & - & $\mathrm{Br}$ \\
\hline & & Elfia sp. & - & $\mathrm{X}$ & - & - & $\mathrm{Co}$ \\
\hline & & Not specified & - & $\mathrm{X}$ & - & - & A \\
\hline & Trichogrammatidae & Trichogramma sp. & $\mathrm{X}$ & - & - & - & $\mathrm{Cl}$ \\
\hline & & Trichogramma bactrae & $X$ & - & - & - & $\mathrm{A}, \mathrm{Cl}$ \\
\hline & & Trichogramma dendrolimi & $X$ & - & - & - & $\mathrm{Cl}$ \\
\hline & & Trichogramma exiguum & $X$ & - & - & - & Co \\
\hline & & Trichogramma fasciatum & $X$ & - & - & - & A \\
\hline & & Trichogramma lopezandinensis & $X$ & - & - & - & $\mathrm{P}$ \\
\hline & & Trichogramma minutum & $X$ & - & - & - & $\mathrm{Cl}, \mathrm{P}$ \\
\hline & & Trichogramma nerudai & $\mathrm{X}$ & - & - & - & $\mathrm{A}, \mathrm{Cl}$ \\
\hline & & Trichogramma pintoi & $\mathrm{X}$ & - & - & - & $\mathrm{P}$ \\
\hline & & Trichogramma pretiosum & $\mathrm{X}$ & - & - & - & $\mathrm{A}, \mathrm{Br}, \mathrm{Co}, \mathrm{Pa}, \mathrm{Cl}, \mathrm{Ve}$ \\
\hline & & Trichogramma rojasi & $X$ & - & - & - & A \\
\hline & & Trichogramma telengai & $X$ & - & - & - & $\mathrm{Cl}$ \\
\hline
\end{tabular}


and Eulophidae contain key parasitoids, a few of which have been used in biological control efforts. In Argentina, several species have been reported, with Pseudapanteles dignus (Braconidae) and Dineulophus phthorimaeae (Eulophidae) as the most commonly found in commercial tomato crops (Berta and Colomo 2000), causing parasitism levels up to $70 \%$ (Sánchez et al. 2009). Other potentially important species are Neochrysocharis formosa and Clostrocerus formosus (Luna et al. 2005; Luna and Wada 2006). In Chile, two parasitoids cause considerable mortality in T. absoluta larvae: Retisympiesis phthorimaea (Eulophidae) with parasitism levels up to $40 \%$ (Rojas 1981) and Dineulophus phthormiaeae causing $39.5 \%$ parasitism (Larraín 1986b). In Brazil, larval parasitoids appear less important, with larval parasitism levels of $0.1-16.8 \%$ by Goniozus nigrifemur (Bethylidae), Bracon sp., Bracon lucileae, Chelonus sp. and Earinus sp. (Braconidae), Diadegma sp. (Ichneumonidae) in tomato crops (Uchôa-Fernandes and Campos 1993; Miranda et al. 1998, 2005; Marchiori et al. 2004; Bacci et al. 2008). The braconid B. lucileae was earlier reported as parasitoid of T. absoluta in the Neotropics (Marsh 1979). Finally, in Colombia a broad complex of larval parasitoids has been reported (Oatman and Platner 1989), of which Apanteles gelechiidivoris (Braconidae) has received particular attention (Vallejo 1999). Regionally, Tachinidae proved of rather negligible importance, with scattered reports from Colombia and Argentina (Oatman and Platner 1989; Colomo and Berta 2006).

In a few South American countries, rather isolated efforts have been conducted to quantify the potential efficacy of various larval parasitoids for T. absoluta biological control. In Argentina, extensive research has been carried out on D. phthorimaea biology (Luna and Wada 2006), and $P$. dignus biology, life history and parasitism behaviour under field conditions (Luna et al. 2007; Sánchez et al. 2009). Primarily based on Argentinean findings, Polack (2007) indicates major potential of $P$. dignus for T. absoluta biological control, hinting that its use may be more efficient and cost-effective than Trichogramma spp. or other larval parasitoids. Control efficacy by $P$. dignus is currently evaluated in commercial tomato fields (Cáceres 2007).

Larval parasitoids have been shipped extensively within and among countries in South America, as part of either personal initiatives or orchestrated classical biological control efforts. For example, A. gelechiidivoris from Colombia was introduced in Chile in the mid 1980s (Rojas 1997). This species was subsequently shipped together with D. phthorimaeae to Easter Island, where it caused substantial drops in T. absoluta infestation levels (Ripa et al. 1995). In mainland Chile, A. gelechiidivoris initially appeared not to establish successfully, until high levels of parasitism were recorded in both open-field and greenhouse tomato production 10 years after its initial introduction.
This wasp was also released in Hawaii for control of tomato pinworm, Keiferia lycopersicella (Nakao and Funasaki 1979).

As for pupal parasitoids, the low number of records may signal an urgent need for additional research, as pupae are rarely included in parasitoid sampling. Nevertheless, Polack (2007) report pupal parasitism levels that regularly surpass $30 \%$. No reports exist of parasitoids of T. absoluta adults.

\section{Arthropod predators}

In comparison with a fairly advanced understanding of T. absoluta parasitism in various South American countries, limited research has been done on arthropod predators. This lack of research attention is unfortunate as predators could be responsible for up to $79.4 \%$ larval mortality and egg predation amounts to $5 \%$ (Miranda et al. 1998). A broad diversity of predators has been found in association with T. absoluta in tomato fields (Table 4). In Brazil, Miranda et al. (2005) indicated presence of Araneidae, Anthicus sp. (Coleoptera: Anthicidae), Cycloneda sanguinea (Coleoptera: Coccinellidae), Staphylinidae, Orius sp. and Xylocoris sp. (Hemiptera: Anthocoridae), Formicidae and Phlaeothripidae, and similarly diverse arthropod complexes have been reported in other studies (Bergmann et al. 1984, 1988).

Among the reported insect species or groups, Xylocoris sp., $C$. sanguinea and members of Phlaeothripidae proved to be key predators of both egg and larval $T$. absoluta stages in Brazil (Miranda et al. 1998). In Venezuela, another anthocorid, Orius insidiosus is reported to be an important predator of $T$. absoluta eggs and larvae (Salas 1995). Vargas (1970) indicates that Nabis sp. (Heteroptera: Nabidae), Polistes sp. (Hymenoptera: Vespidae) and spiders are predators of T. absoluta in Chilean tomato fields. In Brazil, a particular group of Vespidae is reported to contain predators of $T$. absoluta, with Protonectarina sylveirae inflicting 29.3-37.4\% T. absoluta larval mortality (Bacci et al. 2008). Although more exhaustive survey study remains to be conducted, Probst et al. (1999) hint the importance of pupal predators such as Labidura riparia (Dermaptera: Labiduridae), Solenopsis geminata, Pheidole spp. (Hymenoptera: Formicidae), wolf spiders (Araneae: Lycosidae) and ground beetles. Finally, some insect families reported by Miranda et al. (2005) possibly include predators of $T$. absulta pupal or adult stages.

Some predator species have received attention as biological control agents for T. absoluta. Oliveira et al. (2007) indicate that the mite Pyemotes sp., feeds on T. absoluta larvae, pupae and adults and hint its potential use in biological control of the pest. The predatory stinkbug Podisus nigrispinus (Heteroptera: Pentatomidae) has received vast scientific attention, with baseline research done on its life 
Table 4 Arthropod predators associated with different developmental stages of Tuta absoluta in South America ( $E$ egg, $L$ larvae, $P$ pupae, $A$ adult)

\begin{tabular}{|c|c|c|c|c|c|c|c|}
\hline \multirow[t]{2}{*}{ Order } & \multirow[t]{2}{*}{ Family } & \multirow[t]{2}{*}{ Species } & \multicolumn{4}{|c|}{ T. absoluta susceptible stage } & \multirow[t]{2}{*}{ Location } \\
\hline & & & $\mathrm{E}$ & $\mathrm{L}$ & $\mathrm{P}$ & A & \\
\hline Acari & Pyemotidae & Pyemotes sp. & - & $X$ & $X$ & $\mathrm{X}$ & $\mathrm{Br}$ \\
\hline \multirow[t]{5}{*}{ Araneae } & Gnaphosidae & Not specified & $?$ & $?$ & $?$ & $?$ & $\mathrm{Br}$ \\
\hline & Lycosidae & Not specified & - & $\mathrm{X}$ & $\mathrm{X}$ & - & $\mathrm{E}$ \\
\hline & Oxiopidae & Not specified & $?$ & $?$ & $?$ & $?$ & $\mathrm{Br}$ \\
\hline & Salticidae & Not specified & $?$ & $?$ & $?$ & $?$ & $\mathrm{Br}$ \\
\hline & Thomisidae & Not specified & $?$ & $?$ & $?$ & $?$ & $\mathrm{Br}$ \\
\hline \multirow[t]{9}{*}{ Coleoptera } & Carabidae & Not specified & - & - & $X$ & - & $\mathrm{E}$ \\
\hline & & Calosoma sp. & - & $\mathrm{X}$ & $\mathrm{X}$ & - & $\mathrm{Br}$ \\
\hline & & Calosoma granulatum & - & $\mathrm{X}$ & $\mathrm{X}$ & - & $\mathrm{Br}$ \\
\hline & & Lebia sp. & - & $\mathrm{X}$ & $\mathrm{X}$ & - & $\mathrm{Br}$ \\
\hline & & Lebia concina & - & $\mathrm{X}$ & $\mathrm{X}$ & - & $\mathrm{Br}$ \\
\hline & & Selenophorus sp. & - & $X$ & $\mathrm{X}$ & - & $\mathrm{Br}$ \\
\hline & Coccinellidae & Coleomegilla maculata & $X$ & $\mathrm{X}$ & - & - & $\mathrm{Br}$ \\
\hline & & Cycloneda sanguinea & $\mathrm{X}$ & - & - & - & $\mathrm{Br}$ \\
\hline & & Eriopsis conexa & $X$ & - & - & - & $\mathrm{Br}$ \\
\hline \multirow[t]{2}{*}{ Dermaptera } & Labiduridae & Doru lineare & $X$ & - & - & - & $\mathrm{Br}$ \\
\hline & & Labidura riparia & - & - & $\mathrm{X}$ & - & $\mathrm{E}$ \\
\hline \multirow[t]{8}{*}{ Hemiptera } & Anthocoridae & Xylocoris sp. & $X$ & $\mathrm{X}$ & - & - & $\mathrm{Br}$ \\
\hline & & Orius sp. & $X$ & $\mathrm{X}$ & - & - & $\mathrm{Br}$ \\
\hline & & Orius insidiosus & $X$ & $X$ & - & - & $\mathrm{Ve}$ \\
\hline & Geocoridae & Geocoris sp. & $X$ & $\mathrm{X}$ & - & - & $\mathrm{Br}$ \\
\hline & Nabidae & Nabis sp. & - & $X$ & - & - & $\mathrm{Br}, \mathrm{Cl}$ \\
\hline & Pentatomidae & Podisus nigrispinus & - & $X$ & - & - & $\mathrm{Br}$ \\
\hline & Phymatidae & Phymata sp. & - & $\mathrm{X}$ & - & - & $\mathrm{Br}$ \\
\hline & Reduviidae & Debilia sp. & - & $X$ & - & - & $\mathrm{Br}$ \\
\hline \multirow[t]{14}{*}{ Hymenoptera } & Formicidae & Pheidole sp. & - & $\mathrm{X}$ & $\mathrm{X}$ & - & $\mathrm{E}$ \\
\hline & & Solenopsis saevissima & - & $X$ & $X$ & - & $\mathrm{Br}$ \\
\hline & & Solenopsis geminata & - & $X$ & $X$ & - & $\mathrm{E}$ \\
\hline & Vespidae & Protonectarina sylveirae & - & $\mathrm{X}$ & - & - & $\mathrm{Br}$ \\
\hline & & Brachygastra lecheguana & - & $X$ & - & - & $\mathrm{Br}$ \\
\hline & & Polistes sp. & - & $X$ & - & - & $\mathrm{Br}, \mathrm{Cl}$ \\
\hline & & Polistes carnifex & - & $X$ & - & - & $\mathrm{Br}$ \\
\hline & & Polistes melanosoma & - & $\mathrm{X}$ & - & - & $\mathrm{Br}$ \\
\hline & & Polistes versicolor & - & $X$ & - & - & $\mathrm{Br}$ \\
\hline & & Polybia sp. & - & $X$ & - & - & $\mathrm{Br}$ \\
\hline & & Polybia ignobilis & - & $X$ & - & - & $\mathrm{Br}$ \\
\hline & & Polybia scutellaris & - & $\mathrm{X}$ & - & - & $\mathrm{Br}$ \\
\hline & & Protopolybia exigua & - & $X$ & - & - & $\mathrm{Br}$ \\
\hline & & Synoeca cyanea & - & $\mathrm{X}$ & - & - & $\mathrm{Br}$ \\
\hline \multirow[t]{2}{*}{ Neuroptera } & Chrysopidae & Chrysoperla sp. & - & $X$ & - & - & $\mathrm{Br}$ \\
\hline & & Chrysopa sp. & - & $\mathrm{X}$ & - & - & $\mathrm{Br}$ \\
\hline \multirow[t]{3}{*}{ Thysanoptera } & Aeolothripidae & Franklinothrips vespiformis & $X$ & - & - & - & $\mathrm{Br}$ \\
\hline & Phlaeothripidae & Not specified & $X$ & - & - & - & $\mathrm{Br}$ \\
\hline & Thripidae & Scolothrips sexmaculatus & $X$ & - & - & - & $\mathrm{Br}$ \\
\hline
\end{tabular}

Countries in which a given predator is reported from $\mathrm{T}$. absoluta are indicated ( $\mathrm{Br}$ Brazil, $\mathrm{Cl}$ Chile, $\mathrm{E}$ Ecuador, $\mathrm{Ve}$ Venezuela). By no means has the listing been intended to be exhaustive, and its elaboration was based on the available literature sources only 
history (on T. absoluta) (Vivan et al. 2003), predatory behaviour (Vivan et al. 2002) and dispersal in greenhouse environments (Torres et al. 2002). Finally, the green lacewing, Chrysoperla externa, proved to be a good predator of $T$. absoluta larvae under laboratory conditions (Carneiro and Medeiros 1997).

\section{Entomopathogens}

Despite the reported importance of insect pathogens such as Beauveria bassiana (Giustolin et al. 2001a; Rodriguez et al. 2006), their effect on T. absoluta is relatively poorly documented with regard to South America. Among the different entomopathogens that act against $T$. absoluta, B. thuringiensis var. kurstaki (Btk) seems to carry exceptional promise for use in Brazil (Giustolin et al. 2001b). Given that Btk causes mortality in all T. absoluta instars, its combined use with moderately resistant tomato varieties may be worthwhile exploring. Two newly isolated strains of Btk from Chile prove more toxic to larvae than currently available commercial strains (Niedmann and Meza-Basso 2006). In another study, Cry $1 \mathrm{Ab}$ toxin expressed by Bacillus species that naturally colonize the phylloplane of tomato plants was as toxic as the natural one and transformed bacteria survived for extended periods of time (45 days) on the leaf surface (Theoduloz et al. 2003).

\section{Comparative efficacy assessment of natural enemies}

The current state of knowledge regarding natural biological control of T. absoluta in South America may permit pinpointing certain promising agents. However, it does not allow conclusive selection of one or more 'top candidates' for release in Europe. Critical information is lacking on natural enemy biology and ecology, comparative efficacy measures remain to be developed, while survey study is far from complete in many parts of the continent and primarily skewed towards rather conspicuous larval parasitoids and predators.

Little is known regarding relative efficacy of the different agents that occur in various parts of South America. Modest but highly valuable efforts have been done to compare efficacy of some parasitoids, such as $P$. dignus and D. phtoriminaeae (e.g., Sánchez 2010; Savino et al. 2010) or different strains of T. pretiosum (Pratissoli and Parra 2001). Nevertheless, to make valid statements regarding relative efficacy of a given agent, research should urgently be conducted to compare performance of natural enemies that naturally occur in distinct parts of the region, such as $D$. phtoriminaeae in Argentina with A. gelechiidivoris in Colombia, or among the different Trichogramma species and strains that regionally abound. On the other hand, there also is a critical lack of information regarding basic biology and ecology of many natural enemies, which may impede a proper evaluation of their potential for establishment in southern Europe. For example, little research has been done on developmental biology and species' response to selected environmental parameters (e.g., Bajonero et al. 2008).

Despite the current absence of a proper basis for agent selection, an easy and straightforward way of narrowing down the broad suite of candidate natural enemies is to focus on species that effectively control T. absoluta in regions of South America with similar climatic conditions to southern Europe. Employing this selection criterion, one could consider directing research attention to the following set of natural enemies: A. gelechiidivoris, D. phtorimaeae, $P$. dignus, $T$. pretiosum and $P$. nigrispinnus. However, as indicated above, additional applied research should be developed to fully understand the potential of predators, pupal parasitoids and entomopathogens, amongst others.

\section{Potential for classical biological control of $T$. absoluta}

Importation biological control is considered because it could constitute a long-term sustainable management strategy for T. absoluta. However, introducing exotic natural enemies carries unknown level of environmental risk (Wajnberg et al. 2001, van Lenteren et al. 2006) and benefits of such practice must be weighed against its environmental, economic or health risks. We outline below the benefits and eventual risks of importation biological control against $T$. absoluta.

\section{Benefits and potential costs}

The benefits of releasing exotic parasitoids against $T$. $a b$ soluta in the Mediteranean are basically twofold. First, it can lead to a reduction of $T$. absoluta population densities below economic thresholds (Parra and Zucchi 2004; Pratissoli et al. 2005). Second, it can lead to reductions in the use of insecticides, which aside from constituting an important cost component also impact human health and the broader farming environment, including non-target organisms (Weisenburger 1993; Desneux et al. 2007). Also, effective biological control of T. absoluta on tomato can indirectly lead to reduction of damage on alternative host crops.

Effective suppression of T. absoluta populations could also reduce its potential negative impacts, through direct resource competition, or indirectly through apparent competition, on native lepidopteran species (Tilman 1982). Indeed, native Lepidopterous species are likely to occur in natural or agricultural habitats colonized by T. absoluta and thus experience direct resource competition with this pest. 
As for apparent competition, high abundance of T. absoluta could lead to increasing population levels of generalist natural enemies, thus putting other insects at risk (Holt and Lawton 1994; van Veen et al. 2006).

The potential costs of releasing biological control agents include attack of non-target hosts in natural systems and unintended negative indirect effects (Louda et al. 2003; van Lenteren et al. 2006). Among non-target organisms that would be at risk by releases of exotic parasitoids against T. absoluta, particular attention should be paid to endangered and native European Lepidopterous species (Wagner and Van Driesche 2010). Among threatened species, Lepidopterous species from a few number of genus (Cucullia sp., Hyles sp., Maculinea sp., Melanargia sp. Papilio sp. Parnassius sp. and Polyommatus sp.) may be potential hosts for $T$. absoluta parasitoids (including Braconids, Chalcids and Ichneumonids). The introduction of $T$. $a b$ soluta natural enemies may also favour hyperparasitism and lead to a suppression of populations of primary parasitoids via apparent competition (Holt and Lawton 1994; van Veen et al. 2006; Holt and Hochberg 2001). The likelihood of such phenomenon should be minimized by selecting primary parasitoids that present comparatively low susceptibility to hyperparasitoids. Apart from comprehensive host specificity screening and pre-release studies, it is critical to take into account interaction strength between potential biocontrol agents and their hosts as a selection criterion for importation biological control. Natural enemies that fail to effectively reduce densities of the target pest can facilitate bottom-up effects (because of links between the pest and other native organisms through food webs) and could increase the negative impacts of the invasive pest. These indirect effects are potentially more deleterious to native species than direct nontarget effects (Pearson and Callaway 2003).

The decision of importing exotic biological control agents against $T$. absoluta relies mainly on two points (i) the severity of the pest problem in invaded areas, and (ii) how likely the exotic natural enemies will successfully limit $T$. absoluta populations. Given the potential costs raised linked to an importation biological control program against $T$. absoluta, natural enemies have to be chosen carefully to minimize also the risks of unintended side effects. The optimal goal would be importing a highly specific natural enemy and presenting low susceptibility to hyperparasitoids. We need also to stress the need to rigorously assess risks on non-target European lepidopterans. However, it should be pointed out that the degree of damage caused by invading pests to crops or natural ecosystems can often outweigh risks associated with the importation of effective natural enemies previously selected using risk assessment methods (Simberloff and Stiling 1996; Pimentel 2000).

\section{Current management options in Europe and future outlook}

Tuta absoluta has become a severe pest of tomato throughout southern Europe and North Africa, and currently shows considerable potential to expand both host (plant) range and geographic distribution. Appearance of $T$. absoluta has spurred extensive insecticide use by local tomato growers, potentially causing a multitude of undesired side-effects (Weisenburger 1993; Desneux et al. 2007). In addition, future intensive pesticide use may trigger resistance development in T. absoluta. The ongoing spread of T. absoluta throughout Europe, its pest status throughout southern Europe's key tomato production and the lack of totally satisfactory effective management options all signal an urgent need for economically-sound, environmentally-friendly and effective IPM strategies (Monserrat 2009, 2010).

Pest management packages could include cultural, biotechnological, biological and chemical control and thus it may be possible integrating currently available control strategies for T. absoluta to limit its impact in the invaded areas. Firstly, cultural practices such as optimized greenhouse structure, usage of double-door, avoidance of alternative host plants, and removal of infested organs could be of particular value in greenhouses. Then, rigorous sampling protocols need to be adopted that combine pheromone trapping to monitor adult abundance with direct observation to record direct plant damage. Next, different control strategies could be adopted. Once T. absoluta appears in pheromone traps, preventive treatments as $\mathrm{Bt}$ should be initiated and could eventually be integrated with the release or conservation of predatory mirids. In this strategy, releases of the egg parasitoid $T$. achaeae could also be done (Cabello et al. 2009b). Finally, curative treatments with approved insecticides should be applied when dealing with $T$. absoluta outbreak levels.

Within such IPM packages, biological control could be considered as a very promising management tool, with both endemic natural enemies as exotic agents showing certain promise to help keep this invasive pest at bay. In order to fully evaluate the potential of biological control, baseline research needs to be conducted on several fronts. More specifically, advances need to be made in the following areas: (1) detailed survey and works need to be conducted on the nature of the endemic natural enemy complex associated with T. absoluta in different European tomato production regions, (2) assess the potential of native natural enemies to control the pest, (3) define economical thresholds and intervention levels for T. absoluta that account for biological control and (4) carefully balance costs and benefits of classical biological control. In addition, more research is required on the potential for $T$. absoluta to develop on native plants in the invaded areas, and results 
will have to be taken into account for developing a sound pest control strategy.

The challenge of these efforts requires coordinated efforts of European and North African research scientists, management specialists and growers, while banking on long-term experience in South America with T. absoluta management in general, and biological control in particular, to ensure a sustainable management of the pest in its new invaded region.

Ackowledgements We thank José María Guitián Castrillón and Francisco Javier García Domínguez (Tragsatec, Spain) for their involvement on CLIMEX analysis, and comments on an earlier version of the manuscript. We also thank the Editor-in-Chief of Journal of Pest Science for the invitation to submit a review article on Tuta absoluta to the journal.

\section{References}

Apablaza J (1992) La polilla del tomate y su manejo. Tattersal 79: $12-13$

Arnó J, Sorribas R, Prat M, Montse M, Pozo C, Rodriguez D, Garreta A, Gómez A, Gabarra R (2009) Tuta absoluta, a new pest in IPM tomatoes in the northeast of Spain. IOBC/WPRS Bull 49: 203-208

Bacci L, Picando MC, Sousa FF, Silva EM, Campos MR, Tomé HVT (2008) Inimigos naturais da traca do tomateiro. Hortic Bras 26:2808-2812

Bahamondes LA, Mallea AR (1969) Biología en Mendoza de Scrobipalpula absoluta (Meyrick) Povolny (Lepidoptera: Gelechiidae), especie nueva para la República Argentina. Rev Fac Cs Agrarias 15:96-104

Bajonero J, Cordoba N, Cantor F, Rodriguez D, Cure JR (2008) Biology and life cicle of Apanteles gelechiidivoris (Hymenoptera: Braconidae) parasitoid of Tuta absoluta (Lepidoptera: Gelechiidae). Biología y ciclo reproductivo de Apanteles gelechiidivoris (Hymenoptera: Braconidae), parasitoide de Tuta absoluta (Lepidoptera: Gelechiidae). Agron Colomb 26:417-426

Barrientos ZR, Apablaza HJ, Norero SA, Estay PP (1998) Temperatura base y constante térmica de desarrollo de la polilla del tomate, Tuta absoluta (Lepidoptera: Gelechiidae). Ciencia e Investigación Agraria 25:133-137

Bech RA (2009) Federal Order for tomatoes from countries where Tuta absoluta is known to occur. Plant Protection and Quarantine, USDA-APHIS, $3 \mathrm{pp}$

Benitez EA (2000) Levantamiento, identificacion y cria de avispas parasites (Trichogramma spp.) con fines de uso en control biologico de plagas. Revista de Ciencia y Tecnología, Direccion de Investigaciones-UNA 1:15-19

Benvenga SR, Fernandes OA, Gravena S (2007) Decision making for integrated pest management of the South American tomato pinworm based on sexual pheromone traps. Hortic Bras 25: 164-169

Bergmann EC, Imenes SDL, Campos TB, Hojo H, Takematsu AP, Macellaro MIFS (1984) Levantamento da entomofauna em cultura de tomate (Lycopersicum esculetum). O Biológico, São Paulo 50:229-236

Bergmann EC, Imenes SDL, Campos TB, Hojo H, Takematsu AP (1988) Contribuição ao conhecimento da entomofauna em cultura de tomate (Lycopersicum esculentum) através de armadilhas de água. Anais da Sociedade Entomológica do Brasil, Jaboticabal 17:19-40
Berta DC, Colomo MV (2000) Dos especies nuevas de Bracon F. y primera cita para la Argentina de Bracon lucileae Marsh (Hymenoptera, Braconidae), parasitoides de Tuta absoluta (Meyrick) (Lepidoptera: Gelechiidae). Insecta Mundi 14:211-219

Berti J, Marcano R (1995) Preferencia de Trichogramma pretiosum Riley por huevos de diferentes hospederos. Bol Entomol Venez 10:1-5

Betancourt CM, Scatoni IB, Rodríguez JJ (1996) Influencia de la temperatura sobre la reproducción y el desarrollo de Scrobipalpuloides absoluta (Meyrick) (Lepidoptera: Gelechiidae). Rev Bras Biol 56:661-670

Botto EN, Ceriani SA, Lopez SN, Saini ED, Cedola CV, Segade G, Vizcarret M (2000) Control biológico de plagas hortícolas en ambientes protegidos. La experiencia argentina hasta el presente. RIA INTA 29:83-98

Cabello T, Gallego JR, Fernández FJ, Soler A, Beltrán D, Parra A, Vila E (2009a) The damsel bug Nabis pseudoferus (Hem.: Nabidae) as a new biological control agent of the South American Tomato Pinkworm, Tuta absoluta (Lep.: Gelechiidae), in tomato crops of Spain. OIBC/WPRS Bull 49:219-223

Cabello T, Gallego JR, Vila E, Soler A, del Pino M, Carnero A, Hernández-Suárez E, Polaszek A (2009b) Biological control of the South American tomato pinworm. Tuta absoluta (Lep.: Gelechiidae), with releases of Trichogramma achaeae (Hym.: Trichogrammatidae) in tomato greenhouses of Spain. IOBC/ WPRS Bull 49:225-230

Cáceres S (1992) La polilla del tomate en Corrientes. Biología y control. Estación Experimental Agropecuaria Bella Vista, INTA, $19 \mathrm{pp}$

Cáceres S (2007) Manejo de la polilla del tomate en Corrientes. Hoja de Divulgación No 32. Estacion Experimental Agropecuaria Bella Vista. Instituto Nacional de Tecnología Agropecuaria, Bella Vista, Argentina

Calvo FJ, Belda JE, Giménez A (2010) Una estrategia para el control biológico de mosca blanca y Tuta absoluta en tomate. Phytoma España 216:46-52

Campos RG (1976) Control químico del "minador de hojas y tallos de la papa" (Scrobipalpula absoluta Meyrick) en el valle del Cañete. Rev Per Entomol 19:102-106

Campos ML, de Almeida M, Rossi ML, Martinelli AP, Litholdo CG, Figueira A, Rampelotti-Ferreira FT, Vendramim JD, Benedito VA, Peres LEP (2009) Brassinosteroids interact negatively with jasmonates in the formation of anti-herbivory traits in tomato. $\mathrm{J}$ Exp Bot 60:4346-4360

Caponero A (2009) Solanacee, rischio in serre. Resta alta l'attenzione alla tignola del pomodoro nelle colture protette. Colture Protette 10:96-97

Carneiro JR, Medeiros MA (1997) Potencial de consumo de Chrysoperla externa (Neuroptera: Chrysopidae) utilizando ovos de Tuta absoluta (Lepidoptera: Gelechiidae). In: Abstracts of Congresso Brasileiro de Entomologia, vol 16, Salvador, Brazil pp 117-118

Chen RL, Bao XZ, Drake VA, Farrow RA, Wang SY, Sun YJ, Zhai BP (1989) Radar observations of the spring migration into northeastern China of the oriental armyworm moth, Mythimna separata, and other insects. Ecol Entomol 14:149-162

Cisneros F, Mujica N (1998) The leafminer fly in potato plant reactions and natural enemies as natural mortality factors. CIP (Peru) Program report 1997-1998, pp 129-140

Clarke JF (1962) New species of microlepidoptera from Japan. Entomol News 73:102

Clavero M, García-Berthou E (2005) Invasive species are a leading cause of animal extinctions. Trends Ecol Evol 20:110

Coelho MCF, França FH (1987) Biologia e quemotaxia da larva e descrição da pupa e adulto da traça-do-tomateiro. Pesqui Agropecu Bras 22:129-135 
Colomo MV, Berta DC (2006) Primer registro de un Exoristini (Diptera: Tachinidae) en Tuta absoluta (Lepidoptera: Gelechiidae). Acta Zool Lilloana 50:123-124

Colomo MV, Berta DC, Chocobar MJ (2002) El complejo de himenópteros parasitoides que atacan a la "polilla del tomate" Tuta absoluta (Lepidoptera: Gelechiidae) en la Argentina. Acta Zool Lilloana 46:81-92

da Cunha US, Vendramim JD, Rocha WC, Vieira PC (2005) Potential of Trichilia pallida Swartz (Meliaceae) as a source of substances with insecticidal activity against the tomato leafminer Tuta absoluta (Meyrick) (Lepidoptera: Gelechiidae). Neotrop Entomol 34:667-673

da Cunha US, Vendramim JD, Rocha WC, Vieira PC (2006) Fractions of Trichilia pallens with insecticidal activity against Tuta absoluta. Pesqui Agropecu Bras 41:1579-1585

da Cunha US, Vendramim JD, Rocha WC, Vieira PC (2008) Bioactivity of Trichilia pallida Swartz (Meliaceae) derived molecules on Tuta absoluta (Meyrick) (Lepidoptera: Gelechiidae). NeotropEntomol 37:709-715

de Oliveira CRF, Matos CHC, Hatano E (2007) Occurrence of Pyemotes sp on Tuta absoluta (Meyrick). Braz Arch Biol Techn 50:929-932

de Resende JTV, Maluf WR, Faria MV, Pfann AZ, do Nascimento ER (2006) Acylsugars in tomato leaflets confer resistance to the South American tomato pinworm, Tuta absoluta Meyr. Sci Agric 63:20-25

Decoin M (2010) Tomate, Tuta absoluta touche à l'Atlantique. Phytoma 631:44-45

Delbene JA (2003) Evaluación de cepas nativas de los hongos entomopatógenos Beauveria sp. y Metarhizium sp. sobre el control de polilla del tomate Tuta absoluta Meyrick. Pontificia Universidad Católica de Valparaíso, Chile, $41 \mathrm{pp}$

Desneux N, Decourtye A, Delpuech JM (2007) The sublethal effects of pesticides on beneficial arthropods. Annu Rev Entomol $52: 81-106$

EC Report (2009) Summary report of the meeting of the standing committee on plant health, D(2009)411880, 19-20 Oct 2009, 5 pp

EPPO (2005) Data sheets on quarentine pests: Tuta absoluta. OEPP/ EPPO Bul 35:434-435

EPPO (2009) EPPO Reporting service-Pest \& Diseases. No 8, Paris, 2009-08-01

EPPO (2010) EPPO Reporting service-Pest \& Diseases. No 1, Paris, 2010-01-01

Estay P (2000) Polilla del Tomate Tuta absoluta (Meyrick) [WWW document]. URL http://alerce.inia.cl/docs/Informativos/ Informativo09.pdf. Accesed 2 Feb 2010

Estay P, Bruna A (2002) Insectos y ácaros asociados al tomate en Chile. In: Estay P, Bruna A (eds) Insectos, ácaros y enfermedades asociados al tomate en Chile. Centro regional de Investigación INIA La Platina, Santiago, Chile, pp 9-22

Faccioli G (1993) Relationship between males caught with low pheromone doses and larval infestation of Argyrotaenia pulchellana. Entomol Exp Appl 68:165-170

Feng HQ, Wu KM, Ni YX, Cheng DF, Guo YY (2005) High-altitude windborne transport of Helicoverpa armigera (Lepidoptera: Noctuidae) in mid-summer in northern China. J Insect Behav 18:335-349

Fernández S, Montagne A (1990) Biología del minador del tomate, Scrobipalpula absoluta (Meyrick) (Lepidoptera: Gelechiidae). Bol Entomol Venez 5:89-99

Fitt GP (1989) The ecology of Heliothis species in relation to agroecosystems. Annu Rev Entomol 34:17-52

Gabarra R, Arnó J (2010) Resultados de las experiencias de control biológico de la polilla del tomate en cultivo de invernadero y aire libre en Cataluña. Phytoma España 217:65-68
Garcia MF, Espul JC (1982) Bioecología de la polilla del tomate (Scrobipalpula absoluta) en Mendoza, República Argentina. Rev Invest Agropecuarias INTA (Argentina) 18:135-146

Gerding MP, Torres CP (2003) Control Biológico de Tuta absoluta con Trichogramma nerudai y Trichogrammatoidea bactrae. In: Libro de resúmenes del $54^{\circ}$ Congreso Agronómico de Chile y $4^{\circ}$ Congreso de la Sociedad Chilena de Fruticultura. Torres del Paine (XII Región), Chile, p 39

Germain JF, Lacordaire AI, Cocquempot C, Ramel JM, Oudard E (2009) Un nouveau ravageur de la tomate en France: Tuta absoluta. PHM-Revue Horticole 512:37-41

Giustolin TA, Vendramim JD, Alves SB, Vieira SA (2001a) Pathogenicity of Beauveria bassiana (Bals.) Vuill. to Tuta absoluta (Meyrick) (Lepidoptera: Gelechiidae) reared on two genotypes of tomato. Neotrop Entomol 30:417-421

Giustolin TA, Vendramim JD, Alves SB, Vieira SA (2001b) Susceptibility of Tuta absoluta (Meyrick) (Lep, Gelechiidae) reared on two species of Lycopersicon to Bacillus thuringiensis var. kurstaki. J Appl Entomol 125:551-556

Goncalves-Gervasio RDR, Vendramim JD (2007) Bioactivity of aqueous neem seeds extract on the Tuta absoluta (Meyrick, 1917) (Lepidoptera: Gelechiidae) in three ways of application. Cienc Agrotec 31:28-34

González-Cabrera J, Mollá O, Montón H, Urbaneja A (accepted) Efficacy of Bacillus thuringiensis (Berliner) for controlling the tomato borer, Tuta absoluta (Meyrick) (Lepidoptera: Gelechiidae). Biocontrol

Haack RA, Herard F, Sun JH, Turgeon JJ (2010) Managing invasive populations of Asian longhorned beetle and citrus longhorned beetle: a worldwide perspective. Annu Rev Entomol 55:521-546

Haji FNP (1997) Controle biológico da traca do tomateiro com Trichogramma no Nordeste do Brasil. In: Parra JRP, Zucchi RA (eds), Trichogramma e o controle biológico aplicado. FEALQ, Piracicaba, Brasil, pp 319-324

Haji FNP (2002) Trichogramma pretiosum para controle de pragas no tomateiro industrial. In: Parra JRP, Botelho SM, Ferreira BSC, Bento JMS (eds) Controle biológico no Brasil: Parasitóides e predadores. Manole, São Paulo, pp 477-494

Holt RD, Hochberg ME (2001) Indirect interactions, community modules and biological control: a theoretical perspective. In: Wajnberg E, Scott JK, Quimby PC (eds) Evaluating indirect ecological effects of biological control. CABI Publishing, Wallingford, pp 13-37

Holt RD, Lawton JH (1994) The ecological consequences of shared natural enemies. Annu Rev Ecol Syst 25:495-520

Jimenez M, Bobadilla D, Vargas H, Taco E, Mendoza R (1998) Nivel de daño de Tuta absoluta (Meyrick), (Lepidóptera: Gelechiidae), en cultivos experimentales de tomate sin aplicación de insecticidas convencionales. Sociedad Chilena de Entomología Universidad de Concepción. XX Congreso Nacional de Entomología. Concepción, 11, 12 y 13 de noviembre 1998, pp 43-51

Kılıç T (2010) First record of Tuta absoluta in Turkey. Phytoparasitica. doi:10.1007/s12600-010-0095-7

Klein Koch C (1977) Aspectos generales del control biologico e integrado de plagas en Chile. Bol Serv Plagas 3:121-132

Larraín PS (1986a) Plagas del tomate. IPA, La Platina 39:30-35

Larraín PS (1986b) Total mortality and parasitism of Dineulophus phtorimaeae (De Santis) in tomato moth larvae, Scrobipalpula absoluta (Meyrick). Agric Tec (Chile) 46:227-228

Lavandero B, Muñoz C, Barrios W (2006) The Achilles' heel of biological control: a new vision for your success. Agro-Ciencia 22:111-123

Lietti MMM, Botto E, Alzogaray RA (2005) Insecticide Resistance in Argentine Populations of Tuta absoluta (Meyrick) (Lepidoptera: Gelechiidae). Neotrop Entomol 34:113-119 
López E (1991) Polilla del tomate: Problema crítico para la rentabilidad del cultivo de verano. Empresa y Avance Agrícola 1:6-7

Louda SM, Pemberton RW, Johnson MT, Follett PA (2003) Nontarget effects - the Achilles' heel of biological control? Retrospective analyses to reduce risk associated with biocontrol introductions. Annu Rev Entomol 48:365-396

Luna MG, Wada V (2006) Ectoparasitoides (Hymenoptera: Eulophidae) de la polilla del tomate, Tuta absoluta (Meyrick) (Lepidoptera: Gelechiidae): Abundancia estacional y biología en el laboratorio. 1ra Reunión Argentina de Parasitoides-Sección Ecología de poblaciones y comunidades Bariloche 2006

Luna MG, Nieves E, Estivariz MC, Wada V (2005) Closterocerus formosus y Dineulophus phtorimaeae (Hymenoptera: Eulophidae) ectoparasitoides de Tuta absoluta en cultivos de tomate: estudio comparativo para su identificacion. Actas del VI Congreso Argentino de Entomologia, 12-15 September 2005, Tucumán, Argentina

Luna MG, Sánchez N, Pereyra PC (2007) Parasitism of Tuta absoluta (Lepidoptera, Gelechiidae) by Pseudapanteles dignus (Hymenoptera, Braconidae) under laboratory conditions. Environ Entomol 36:887-893

Mack RN, Barrett SCH, deFur PL, MacDonald WL, Madden LV, Marshall DS, McCullough DG, McEvoy PB, Nyrop JP, Reichard SEH, Rice KJ, Tolin SA (2002) Predicting invasions of nonidigenous plants and plant pests. National Academy of Sciences, Washington, DC

Maluf WR, Maciel GM, Gomes LAA, Cardoso MD, Goncalves LD, da Silva EC, Knapp M (2010) Broad-spectrum arthropod resistance in hybrids between high- and low-acylsugar tomato lines. Crop Sci 50:439-450

Marcano R (1995) Efecto de la temperatura sobre el desarrollo y la reproducción de Scrobipalpula absoluta (Meyrick) (Lepidoptera: Gelechiidae). Bol Entomol Venez 10:69-75

Marchiori CH, Silva CG, Lobo AP (2004) Parasitoids of Tuta absoluta (Meyrick, 1917) (Lepidoptera: Gelechiidae) collected on tomato plants in Lavras, state of Minas Gerais, Brazil. Braz J Biol 64:551-552

Marsh P (1979) Descriptions of new Braconidae (Hymenoptera) parasitic on the potato tuberworm and on related Lepidoptera from Central and South America. J Wash Acad Sci 69:12-16

Medeiros MA (2007) The role of biodiversity in managing the tomato leafminer Tuta absoluta (Meyrick, 1917) (Lepidoptera: Gelechiidae). Doctoral Dissertation, University of Brasilia, $145 \mathrm{pp}$

Medeiros MA, Villas Bôas GL, Vilela NJ, Carrijo AO (2009a) A preliminar survey on the biological control of South American tomato pinworm with the parasitoid Trichogramma pretiosum in greenhouse models. Hortic Bras 27:80-85

Medeiros MA, Sujii ER, Rasi GC, Liz RS, de Morais HC (2009b) Oviposition pattern and life table of South American tomato pinworm Tuta absoluta (Meyrick) (Lepidoptera, Gelechiidae). Rev Bras Entomol 53:452-456

Miranda MMM, Picanco M, Zanuncio JC, Guedes RNC (1998) Ecological Life Table of Tuta absoluta (Meyrick) (Lepidoptera: Gelechiidae). Biocontrol Sci Technol 8:597-606

Miranda MMM, Picanço MC, Zanuncio JC, Bacci L, da Silva EM (2005) Impact of integrated pest management on the population of leafminers, fruit borers, and natural enemies in tomato. Cienc Rural 35:204-208

Mollá O, Montón H, Beitia Crespo FJ, Urbaneja A (2008) La polilla del tomate Tuta absoluta (Meyrick), una nueva plaga invasora. Terralia 69:36-42

Mollá O, Montón H, Vanaclocha P, Beitia F, Urbaneja A (2009) Predation by the mirids Nesidiocoris tenuis and Macrolophus pygmaeus on the tomato borer Tuta absoluta. IOBC/WPRS Bull 49:209-214
Mollá O, Alonso M, Montón H, Beitia F, Verdú MJ, GonzálezCabrera J, Urbaneja A (2010) Control Biológico de Tuta absoluta. Catalogación de enemigos naturales y potencial de los míridos depredadores como agentes de control. Phytoma España 217:42-46

Monserrat A (2009) La polilla del tomate Tuta absoluta en la Región de Murcia: bases para su control. Serie Técnica y de Estudios No. 34. Conserjería de Agricultura y Agua

Monserrat A (2010) Estrategias globales en el manejo de Tuta absoluta en Murcia. Phytoma España 217:81-86

Moreira MD, Picanco MC, Barbosa LCD, Guedes RNC, da Silva LM (2004) Toxicity of leaf extracts of Ageratum conyzoides to lepidoptera pests of horticultural crops. Biol Agric Hortic 22:251-260

Nakao HK, Funasaki GY (1979) Introductions for biological control in Hawaii: 1975 \& 1976. Proc Hawaiian Entomol Soc 13:125128

Navarro MA (1986) Biological control of Scrobipalpula absoluta (Meyrick) by Trichogramma sp. in the tomato (Lycopersicon esculentum Mill.). In: 11nd international symposium, Trichogramma and other egg parastoids, Guangzhou, China, pp 453458

Niedmann LL, Meza-Basso L (2006) Evaluación de cepas nativas de Bacillus thuringiensis como una alternativa de manejo integrado de la polilla del tomate (Tuta absoluta Meyrick; Lepidoptera: Gelechiidae) en Chile. Agric Técnica 66:235-246

Notz AP (1992) Distribution of eggs and larvae of Scrobipalpula absoluta in potato plants. Rev Facultad de Agronomía Maracay 18:425-432

Oatman ER, Platner GR (1989) Parasites of the potato tuberworm, tomato pinworm and other closely related Gelechiids. Proc Hawaiian Entomol Soc 29:23-30

Oliveira FA, da Silva DJH, Leite GLD, Jham GN, Picanco M (2009) Resistance of 57 greenhouse-grown accessions of Lycopersicon esculentum and three cultivars to Tuta absoluta (Meyrick) (Lepidoptera: Gelechiidae). Sci Hortic 119:182-187

Olson LJ (2006) The economics of terrestrial invasive species: a review of the literature. Agric Resour Econ Rev 35:178-194

Parra JRP, Zucchi RA (2004) Trichogramma in Brazil: feasibility of use after twenty years of research. Neotrop Entomol 33:271-281

Pearson DE, Callaway RM (2003) Indirect effects of host-specific biological control agents. Trends Ecol Evol 18:456-461

Pereira GVN, Maluf WR, Goncalves LD, do Nascimento DR, Gomes LAA, Licursi V (2008) Selection towards high acylsugar levels in tomato genotypes and its relationship with resistance to spider mite (Tetranychus evansi) and to the South American pinworm (Tuta absoluta). Cienc Agrotec 32:996-1004

Pereyra PC, Sánchez NE (2006) Effect of two solanaceous plants on developmental and population parameters of the tomato leaf miner, Tuta absoluta (Meyrick) (Lepidoptera: Gelechiidae). Neotrop Entomol 35:671-676

Pimentel D (2000) Biological control of invading species. Science 289:869

Polack A (2007) Perspectivas para el control biológico de la polilla de tomate. Horticom News, 8 October 2009

Potting R (2009) Pest risk analysis, Tuta absoluta, tomato leaf miner moth. Plant protection service of the Netherlands, $24 \mathrm{pp}$. www.minlnv.nl

Povolny D (1975) On three neotropical species of Gnorimoschemini (Lepidoptera, Gelechiidae) mining Solanaceae. Acta Univ Agric 23:379-393

Pratissoli D, Parra JRP (2000) Fertility life table of Trichogramma pretiosum (Hym., Trichogrammatidae) in eggs of Tuta absoluta and Phthorimaea operculella (Lep., Gelechiidae) at different temperatures. J Appl Entomol 124:339-342 
Pratissoli D, Parra JRP (2001) Selection of strains of Trichogramma pretiosum Riley (Hymenoptera: Trichogrammatidae) to control the tomato leafminer moths Tuta absoluta (Meyrick) and Phthorimaea operculella (Zeller) (Lepidoptera: Gelechiidae). Neotrop Entomol 30:277-282

Pratissoli D, Thuler RT, Andrade GS, Zanotti LCM, Silva AF (2005) Estimate of Trichogramma pretiosum to control Tuta absoluta in stalked tomato. Pesq Agropec Bras 40:715-718

Probst K, Pülschen L, Sauerborn J, Zebitz CPW (1999) Influencia de varios regímenes de uso de plaguicidas sobre la entomofauna de tomate en las tierras altas de Ecuador. Manejo Integrado de Plagas, No. 54. CATIE, Costa Rica

Ragsdale DW, Landis DA, Brodeur J, Heimpel GE, Desneux N (2011) Ecology and management of the soybean aphid in North America. Annu Rev Entomol (In press)

Ripa SR, Rojas PS, Velasco G (1995) Releases of biological control agents of insect pests on Easter Island (Pacific Ocean). Entomophaga 40:427-440

Riquelme MB, Botto EN (2003) Dispersión y persistencia de Trichogrammatoidea bactrae (Hymenoptera: Trichogrammatidae) en cultivo de tomate bajo cubierta. Resúmenes XXV Cong. Chil. de Entomol., Talca, Chile, 23 pp

Roditakis E, Papachristos D, Roditakis NE (2010) Current status of the tomato leafminer Tuta absoluta in Greece. OEPP/EPPO Bul 40:163-166

Rodriguez MS, Gerding MP, France AI (2006) Entomopathogenic fungi isolates selection for egg control of tomato moth Tuta absoluta Meyrick (Lepidoptera: Gelechiidae) eggs. Agric Técnica 66:151-158

Rojas S (1981) Control de la polilla del tomate: enemigos naturales y patógenos. IPA La Platina 8:18-20

Rojas S (1997) Establecimiento de enemigos naturales. Agric Técnica $57: 297-298$

Salas J (1995) Orius insidiosus (Hemiptera: Anthocoridae) su presencia en la region Centro Occidental de Venezuela. Agron Trop 45:637-645

Salas J (2001) Insectos plagas del tomate. Manejo integrado. Maracay, Ven., Instituto Nacional de Investigaciones Agrícolas. Centro de Investigaciones Agropecuarias del Estado Lara (Serie B-No. 1), 102 pp

Salazar ER, Araya JE (1997) Detección de resistencia a insecticidas en la polilla del tomate. Simiente 67:8-22

Samways MJ (2007) Insect conservation: a synthetic management approach. Annu Rev Entomol 52:465-487

Sánchez NE (2010) Ecological studies of two parasitoids of the tomato moth Tuta absoluta: challenges and perspectives for their application in biological control in Argentina. Congress proceedings, IOBC Biological control in the Americas: past, present and future, 11-13 May 2010

Sánchez NE, Pereyra PC, Luna MG (2009) Spatial patterns of parasitism of the solitary parasitoid Pseudapanteles dignus (Hymenoptera: Braconidae) on Tuta absoluta (Lepidoptera: Gelechiidae). Environ Entomol 38:365-374

Sannino L, Espinosa B (2009) Keiferia lycopersicella, una nuova tignola su pomodoro. Informat Agr 4:69-70

Savino V, Coviella CE, Luna MG, Sánchez NE (2010) Functional response of Dineulophus phtorimaeae de Santis (Hymenoptera: Eulophidae), an ectoparasitoid of the tomato moth Tuta absoluta (Meyrick) (Lepidoptera: Gelechiidae) under laboratory conditions. Congress proceedings, IOBC Biological control in the Americas: past, present and future, 11-13 May 2010

Silvério FO, de Alvarenga ES, Moreno SC, Picanço MC (2009) Synthesis and insecticidal activity of new pyrethroids. Pest Manage Sci 65:900-905

Simberloff D, Stiling P (1996) How risky is biological control? Ecology 77:1965-1974
Siqueira HA, Guedes RN, Picanço MC (2000) Insecticide resistance in populations of Tuta absoluta (Lepidoptera: Gelechiidae). Agric For Entomol 2:147-153

Siqueira HAA, Guedes RNC, Fragoso DB, Magalhaes LC (2001) Abamectin resistance and synergism in Brazilian populations of Tuta absoluta (Meyrick) (Lepidoptera: Gelechiidae). Int J Pest Manage 47:247-251

Suckling DM, Brockerhoff EG (2010) Invasion biology, ecology, and management of the light brown apple moth (Tortricidae). Annu Rev Entomol 55:285-306

Sutherst RW, Maywald GF, Kriticos D (2007) CLIMEX ${ }^{\circledR}$ software version 3, User's Guide. CSIRO, Hearne Scientific Software Pty Ltd

Taco E, Quispe R, Bobadilla D, Vargas H, Jimenez M, Morales A (1998) Resultados preliminares de un ensayo de control biológico de la polilla del tomate, Tuta absoluta (Meyrick), en el valle de Azapa. IX Congreso Latino-Americano de Horticultura. Santiago, 30 de Noviembre al 3 de diciembre de 1998, pp 54-56

Tezze AA, Botto EN (2004) Effect of cold storage on the quality of Trichogramma nerudai (Hymenoptera: Trichogrammatidae). Biol Control 30:11-16

Theoduloz C, Vega A, Salazar M, Gonzalez E, Meza-Basso L (2003) Expression of a Bacillus thuringiensis d-endotoxin cry1 Ab gene in Bacillus subtilis and Bacillus licheniformis strains that naturally colonize the phylloplane of tomato plants (Lycopersicon esculentum, Mills). J Appl Microbiol 94:375-381

Thomas MB (1999) Ecological approaches and the development of 'truly integrated' pest management. Proc Natl Acad Sci USA 96:5944-5951

Tilman D (1982) Resource competition and community structure. Princeton University Press, Princeton, New Jersey

Torres JB, Evangelista WS, Barras R, Guedes RNC (2002) Dispersal of Podisus nigrispinus (Het., Pentatomidae) nymphs preying on tomato leafminer: effect of predator release time, density and satiation level. J Appl Entomol 126:326-332

Torres Gregorio J, Argente J, Díaz MA, Yuste A (2009) Applicación de Beauveria bassiana en la lucha biológica contra Tuta absoluta. Agrícola Vergel: Fruticultura, Horticultura, Floricultura 326:129-132

Tropea Garzia G (2009) Physalis peruviana L. (Solanaceae), a host plant of Tuta absoluta in Italy. IOBC/WPRS Bull 49:231-232

Uchôa-Fernandes MA, Campos WG (1993) Parasitoids of larvae and pupae of the tomato worm Scrobipalpuloides absoluta Meyrick, 1917 (Lepidoptera: Gelechiidae). Rev Bras Entomol 37:399-402

Uchôa-Fernandes MA, Della Lucia TMC, Vilela EF (1995) Mating, oviposition and pupation of Scrobipalpula absoluta (Meyrick) (Lepidoptera: Gelechiidae). Anais da Sociedade Entomologica do Brasil 24:159-164

Urbaneja A, Vercher R, Navarro V, García Marí F, Porcuna JL (2007) La polilla del tomate, Tuta absoluta. Phytoma España 194:16-23

Urbaneja A, Montón H, Mollá O (2009) Suitability of the tomato borer Tuta absoluta as prey for Macrolophus caliginosus and Nesidiocoris tenuis. J Appl Entomol 133:292-296

Vallejo FA (1999) Mejoramiento genético y producción de tomate en Colombia. Universidad Nacional de Colombia, 216 pp

van Lenteren JC, Bale J, Bigler E, Hokkanen HMT, Loomans AM (2006) Assessing risks of releasing exotic biological control agents of arthropod pests. Annu Rev Entomol 51:609-634

van Veen FFJ, Rebecca J, Morris H, Godfray CJ (2006) Apparent competition, quantitative food webs, and the structure of phytophagous insect communities. Annu Rev Entomol 51:187208

Vargas HC (1970) Observaciones sobre la biología y enemigos naturales de la polilla del tomate, Gnorimoschema absoluta (Meyrick) (Lepidoptera: Gelechiidae). Idesia 1:75-110 
Vercher R, Calabuig A, Felipe C (2010) Ecología, muestreos y umbrales de Tuta absoluta (Meyrick). Phytoma España 217:23-26

Villas Bôas GL, Franca FH (1996) Utilização do parasitóide Trichogramma pretiosum no controle da traça-dotomateiro em cultivo protegido de tomate. Hortic Bras 14:223-225

Vivan LM, Torres JB, Veiga AFDL, Zanuncio JC (2002) Predatory behavior and food conversion of Podisus nigrispinus preying on tomato leafminer. Pesqui Agropecu Bras 37:581-587

Vivan LM, Torres JB, Veiga AFSL (2003) Development and reproduction of a predatory stinkbug, Podisus nigrispinus, in relation to two different prey types and environmental conditions. Biocontrol 48:155-168

Wagner DL, Van Driesche RG (2010) Threats posed to rare or endangered insects by invasions of non native species. Annu Rev Entomol 55:547-568
Wajnberg EJ, Scott K, Quimby PC (2001) Evaluating indirect ecological effects of biological control. CABI Publishing, New York

Weisenburger DD (1993) Human health: effects of agrichemicals use. Hum Pathol 24:571-576

Whu MP, Valdivieso LJ (1999) Distribución y comportamiento de ocho especies de Trichogramma y Trichogrammatoidea (Hymenoptera: Trichogrammatidae) en el Perú. Rev Per Entomol 41:61-68

Witzgall P, Stelinski L, Gut L, Thomson D (2008) Codling moth management and chemical ecology. Annu Rev Entomol 53:503522

Witzgall P, Kirsch P, Cork A (2010) Sex pheromones and their impact on pest Management. J Chem Ecol 36:80-100 